\title{
Technology Assessment of Dust Suppression Techniques Applied during Structural Demolition
}

\author{
Topical Report \\ August 1, 1995 - October 30, 1996 \\ By: \\ M. A. Ebadian; Joseph F. Boudreaux \\ S. K. Dua; P. T. Williams
}

Work Performed Under Contract No.: DE-FG21-95EW55094

For

U.S. Department of Energy

Office of Fossil Energy

Federal Energy Technology Center

P.O. Box 880

Morgantown, West Virginia 26507-0880

By

Florida International University

Hemispheric Center for Environmental Technology (HCET)

Center for Engineering \& Applied Sciences

10555 West Flagler Street

EAS-2100

Miami, Florida 33174 


\section{Disclaimer}

This report was prepared as an account of work sponsored by an agency of the United States Government. Neither the United States Government nor any agency thereof, nor any of their employees, makes any warranty, express or implied, or assumes any legal liability or responsibility for the accuracy, completeness, or usefulness of any information, apparatus, product, or process disclosed, or represents that its use would not infringe privately owed rights. Reference herein to any specific commercial product, process, or service by trade name, trademark, manufacturer, or otherwise does not necessarily constitute or imply its endorsement, recommendation, or favoring by the United States Government or any agency thereof. The views and opinions of authors expressed herein do not necessarily state or reflect those of the United States Government or any agency thereof. 


\section{DISCLAIMER}

Portions of this document may be illegible in electronic image products. Images are produced from the best available original document. 


\section{TABLE OF CONTENTS}

IIST OF TABIES

LIST OF FIGURES vii

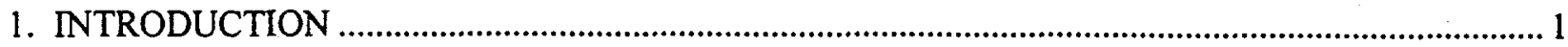

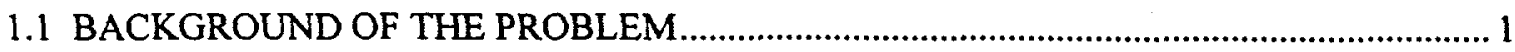

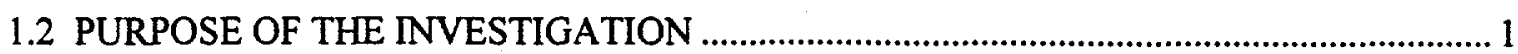

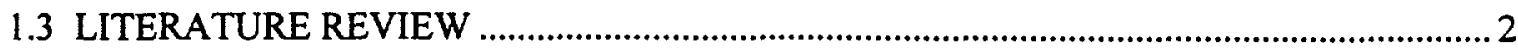

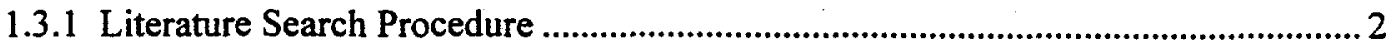

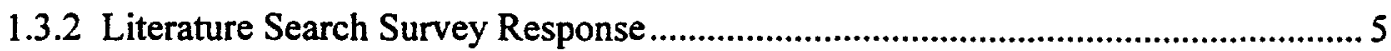

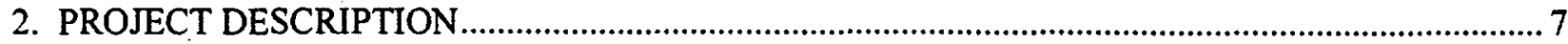

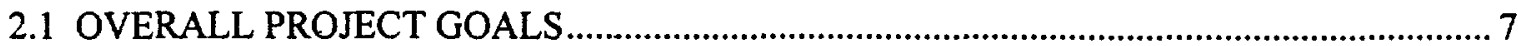

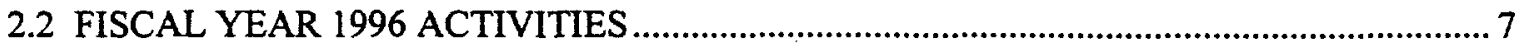

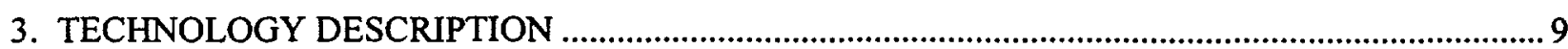

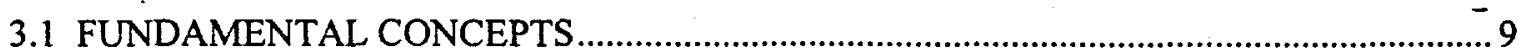

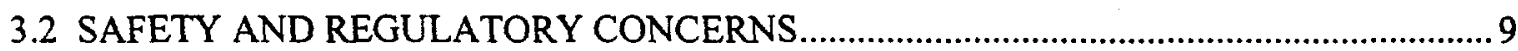

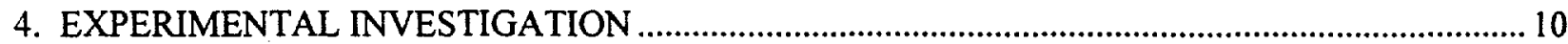

4.1 EXPERIMENTAL SYSTEM DESIGN AND APPARATUS............................................ 10

4.1.1 Instrumentation and Measurements...................................................................... 11

4.1.2 Dust Aerosol Abatement Methods ….......................................................... 12

4.1.3 Test Surrogate Selection and Preparation........................................................... 13

4.1.4 Non-Plastered Concrete Surrogates.................................................................... 14

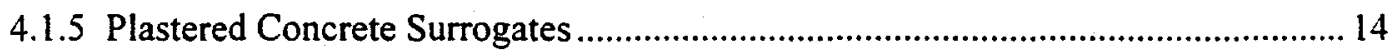

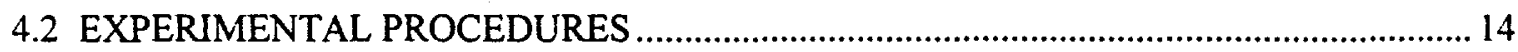

4.2.1 Procedure for the Zero Wind Measurements...................................................... 15

4.2.2 Procedures for Wind Measurements ............................................................. 15

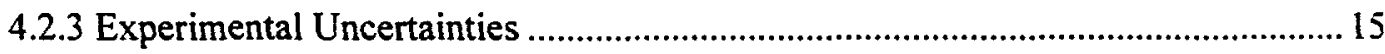

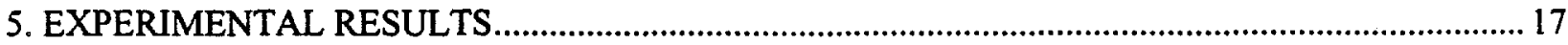

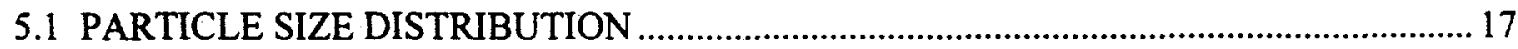

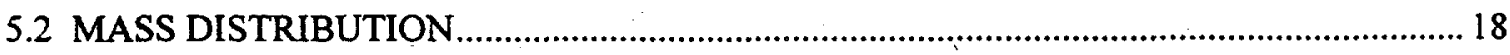

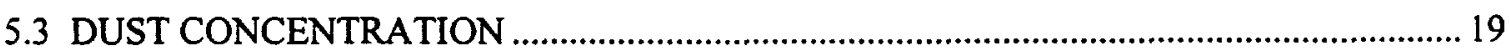

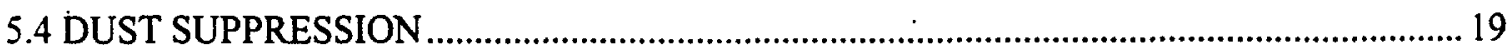

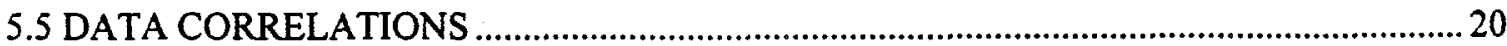

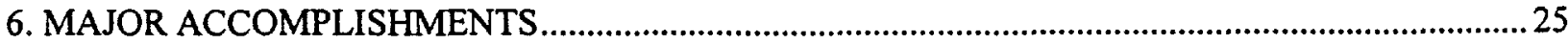

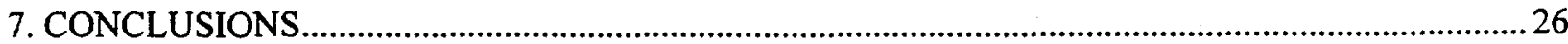

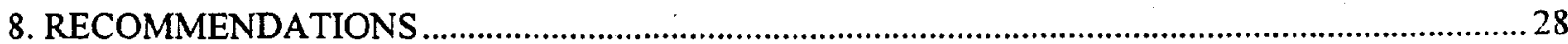

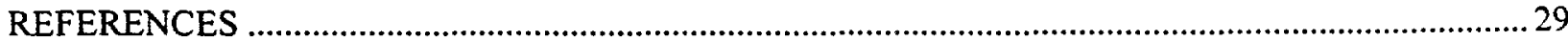


APPENDIX A

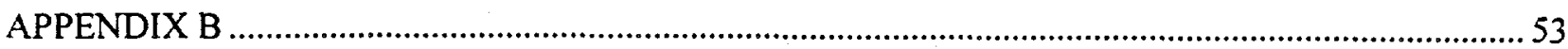




\section{LIST OF TABLES}

Table 1. Structural Demolition and Dust Suppression Techniques ......................................3

Table 2. Effectiveness of Dust Suppression Agents Tested.....................................................19

Appendix A

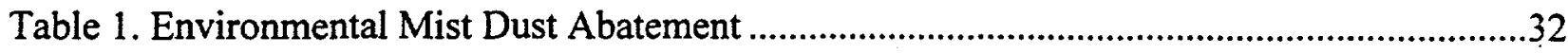

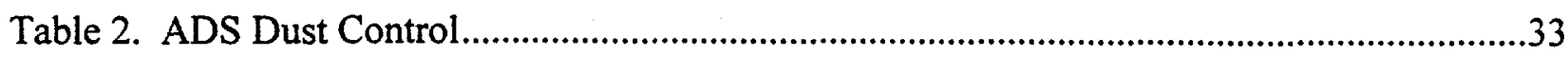

Table 3. High Pressure Water Fog Particle Generation ........................................................33

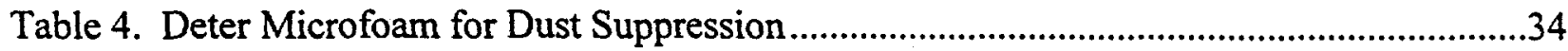

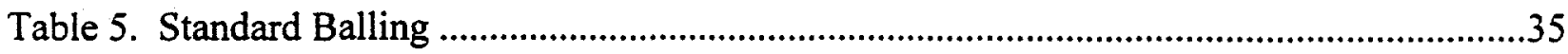

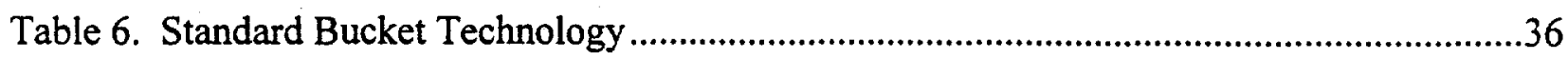

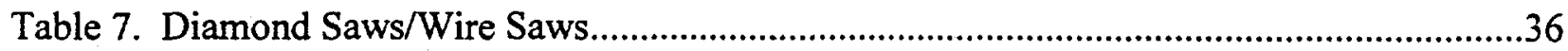

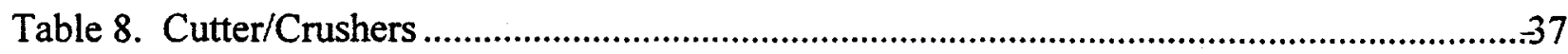

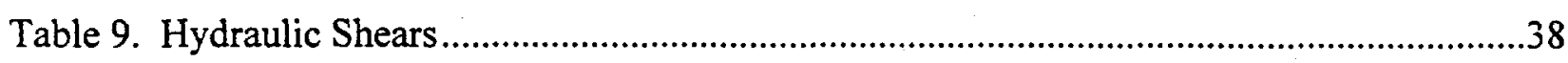

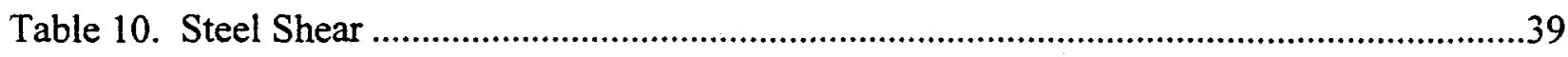

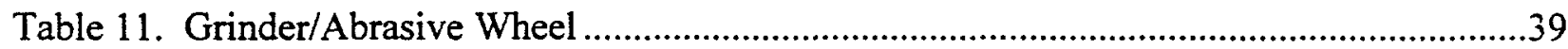

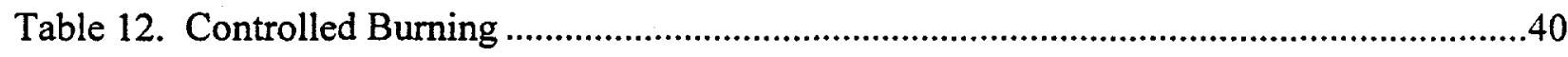

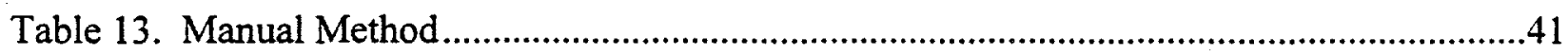

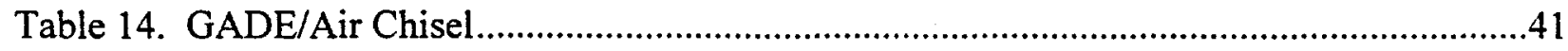

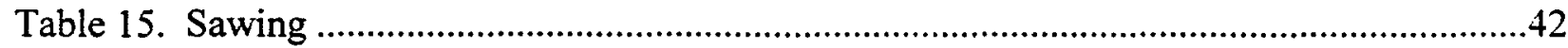

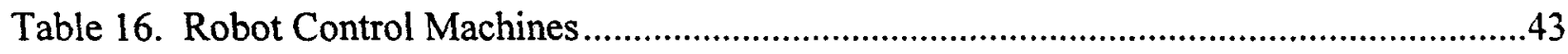

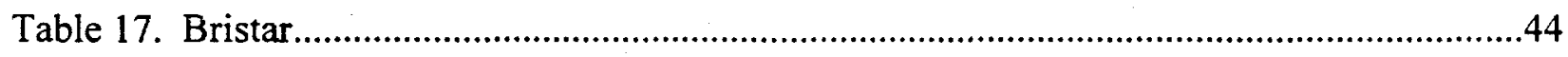

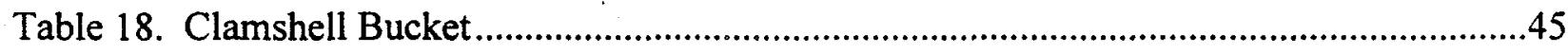

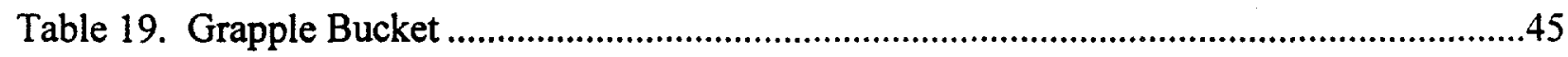

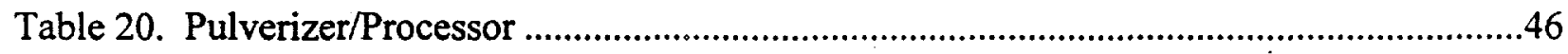

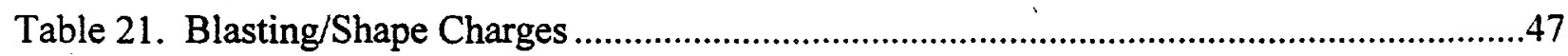

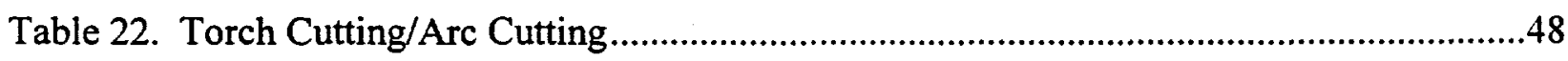

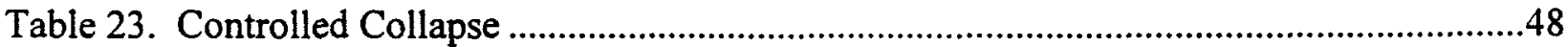

Table 24. High Pressure Water Blasting .............................................................................49

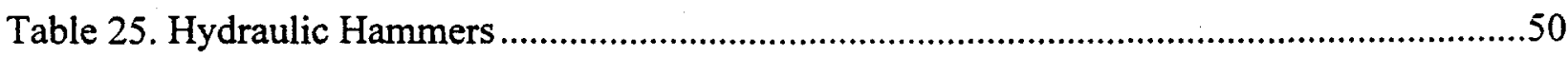

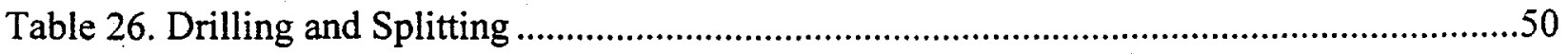




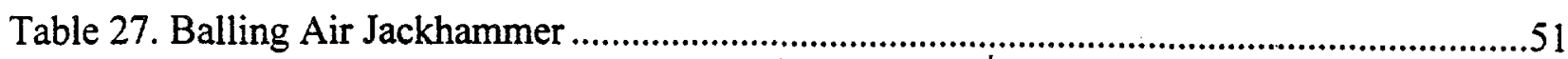

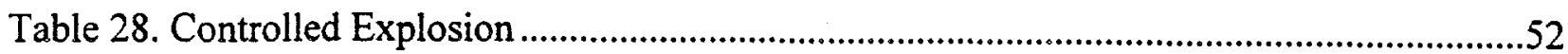


Figure 1. Schematic representation of the experimental system...........................................10

Figure 2. Particle size distribution for the hollow concrete surrogates. No suppression; wind conditions.

Figure 3. Particle size distribution by mass for the hollow concrete surrogates. No suppression; wind conditions.

Figure 4. Mathematical correlation for the solid concrete surrogates. No suppression; wind conditions.

Figure 5. Mathematical correlation for the solid concrete surrogates. Polymeric barrier system; wind conditions.

Figure 6. Mathematical correlation for the solid concrete surrogates. Water additive suppression; wind conditions.

Figure 7. Mathematical correlation for the solid concrete surrogates. Water suppression; wind conditions. 


\section{INTRODUCTION}

\subsection{BACKGROUUND OF THE PROBLEM}

As contaminated buildings throughout the United States Department of Energy (DOE) Complex are demolished, many non-nuclear technologies are being adapted to the nuclear decontamination and decommissioning (D\&D) industry. Factors such as dust generation and health and safety are major concerns when these technologies are applied to building D\&D. As these technologies are applied to specific sites, these factors must be addressed before any D\&D commences. In order to demolish a structure properly and, at the same time, control the amount of dust generated by the given technology, an evaluation must be conducted to choose the most appropriate technology for the task.

Dust suppression is the practice of controlling the amount of particulate matter suspended in air. Dust control is important during building remediation because the inhalation of dust aerosol particles $(<10 \mu \mathrm{m}$ in diameter) is considered a health risk, and these particles may contain contaminants that present an environmental threat. The generation of dust is generally a function of moisture content, the amount of energy delivered to the surface (such as wind or drop height), and the fraction of the surface that is easily entrained into the air. Therefore, dust generation abatement requires that one or more of these factors be controlled:

The principal parameters that must be controlled during D\&D activities are the moisture content and the fraction of the surface that is easily entrained in the air. The moisture content can be increased by the use of water sprays, mists, fogs, or foams. Crusting agents also have the potential of reducing the amount of the surface that is easily entrained in the air during demolition.

\subsection{PURPOSE OF THE INVESTIGATION}

Hanford, Fernald, Savannah River, and other sites are currently reviewing technologies that can be implemented to demolish buildings in a cost-effective manner. In order to demolish a structure properly and, at the same time, minimize the amount of dust generated from a given technology, an evaluation must be conducted to choose the most appropriate dust suppression technology given site-specific conditions.

Thus, the purpose of this research, which was carried out at the Hemispheric Center for Environmental Technology (HCET) at Florida International University, was to conduct an experimental study of dust aerosol abatement (dust suppression) methods as applied to nuclear D\&D. This experimental study targeted the problem of dust suppression during the demolition of nuclear facilities. The resulting data were employed to assist in the development of mathematical correlations that can be applied to predict dust generation during structural demolition.

The project tasks associated with Fiscal Year 1996 (FY96) and Fiscal Year 1997 (FY97) work are listed below: 
Task 1: Literature review of technologies that perform structural demolition as well as those that perform dust suppression (completed in FY96);

Task 2: Review of DOE and commercial sites related to the end use of the material, contaminant of concern, dust generation, costs, schedule, benefits, and health and safety risks (canceled);

Task 3: Development of a test plan to complete a detailed analysis of dust suppression techniques (completed in FY96);

Task 4: Selection and acquisition of technologies to perform a detailed analysis of dust suppression techniques (initiated in FY96 and to be completed in FY97);

Task 5: Laboratory testing of promising dust suppression technologies (initiated in FY96 and to be completed in FY97);

Task 6: Development of extrapolation factors to be applied to building D\&D for dust suppression techniques (initiated in FY96 and to be completed in FY97); and

Task 7: Cost estimates of different dust suppression methods (To be completed in Fiscal Year 1997).

\subsection{LITERATURE REVIEW}

\subsubsection{Literature Search Procedure}

The U.S. Environmental Protection Agency (EPA) and the DOE were contacted to gather information on structural demolition and dust suppression methods. Commercial systems used for non-nuclear demolition and dust suppression were also reviewed for their applicability to nuclear applications. Moreover, Commerce Business Daily $(C B D)$ announcement was placed to solicit techniques used to suppress dust during demolition activities for block walls and poured concrete structures. The Thomas Register and the Florida International University Library LUIS computer data base were also reviewed to query individual commercial companies for the various demolition/dust suppression techniques employed by each vendor. Information gathered for each demolition/dust suppression method included the name of the technology; the vendor's name, address, phone, fax numbers; the demolition/dust abatement method; the benefits and limitations of the technology, applicable building structures, theory of operation, and previous product users.

The survey form which was used to compile information on structural demolition and dust suppression techniques is presented in Table 1. 
Table 1.

Structural Demolition and Dust Suppression Techniques Survey Form

\begin{tabular}{|l|l|}
\hline Tecinoiogy Name & \\
\hline $\begin{array}{l}\text { Technology's Industrial Status } \\
\text { (current or innovative) }\end{array}$ & \\
\hline Vendor & \\
\hline Fax Number & \\
\hline Benefits & \\
\hline Limitations & \\
\hline Method & \\
\hline Applicable Building Type & \\
\hline Theory of Operation & \\
\hline Previous Product Users & \\
\hline
\end{tabular}

The following U.S. government agencies, offices, and sources were also contacted and reviewed to aid in the demolition/dust suppression literature survey:

- U.S. Department of Energy, March 1994, Decommissioning Handbook, DOE/EM-0142P, Office of Environmental Restoration, Oak Ridge, TN.

- Idaho National Engineering Laboratory, January 1994, Idaho National Engineering Laboratory Decontamination and Decommissioning Technology Logic Diagram, U.S. Department of Energy, EGG-WTB-11104,

- United States Department of Energy, Office of Technology Development, Office of Technology Transfer and Program Integration,

- Remedial Action Program Information Center (RAPIC),

- Oak Ridge National Laboratory, 1993, Oak Ridge National Laboratory Logic Diagram, ORNL/M-2752, U.S. Department of Energy,

- United States Department of Energy, Argonne National Laboratory, EM Program Office,

- United States Department of Energy, Albuquerque Operations Office,

- United States Department of Energy, Idaho Operations Office,

- United States Department of Energy, Richland Operations Office, 
- United States Department of Energy, Morgantown (Federal) Energy Technology Center,

- United States Department of Energy, Hanford Operations Office,

- United States Department of Energy, Savannah River Operations Office,

- Center for Environmental Management Information.

The following commercial vendors were also contacted as part of the demolition/dust suppression literature survey:

- Environmental Engineering Concepts, Incorporated;

- International Chimney Corporation;

- Invincible Airflow Systems;

- Technical Ordance;

- Quantic Industries;

- Intersystems, Incorporated;

- Benetech, Incorporated;

- The Raring Corporation;

- Mee Industries;

- Deter Company, Incorporated;

- U.S. Dismantlement;

- Atomizing Systems, Incorporated;

- Pentek;

- Cleveland Wrecking;

- IDM Corporation;

- Babcock and Wilcox;

- Houston Compressed Steel;

- National Association of Demolitionists;

- Manture Construction;

- Allied Demolishment;

- Demolition Technologies;

- Kimmins;

- Holbert Associates;

- Total Energy Corporation;

- Commonwealth Dynamic, Incorporated; 
- International Tank Service;

- Colony Construction;

- Biaster, Incorporated;

- Cutodis;

- Maple Reinders Environmentals;

- Naporano Iron and Steel Company;

- General Electric Corporation;

- Witco Corporation;

- Union Carbide Corporation;

- Spraying Systems Company;

- Bete Fog Nozzle, Incorporated;

- Bartlett Services, Incorporated;

- Aircology, İncorporated;

- New England Demolition;

- Hahn Industries;

- Aquadyne, Incorporated;

- Timfibre, Incorporated; and

- Johnson March Systems.

Based on the results of the literature review, the most promising dust suppression technologies were tested at the Hemispheric Center for Environmental Technology (HCET) on the campus of Florida International University (FIU) to evaluate their effectiveness when applied to different concrete surrogates.

\subsubsection{Literature Search Survey Response}

The survey was conducted in such a way as to include all parties working in the D\&D field. The form was sent to industrial vendors, product vendors, and governmental agencies to identify all current and innovative technologies available for nuclear and non-nuclear remediation. The ensuing lack of response from the survey participants provided insight into the extent of innovative technologies available for $D \& D$ work. This is not to say that there are no dust suppression technologies available but that the technologies that are available are basic in nature as compared to those used for other major D\&D tasks such as characterization.

The results of the literature review have revealed that the methods currently used by industry to demolish buildings are baseline technologies. No currently available innovative technologies provide the resources required for structural demolition at DOE sites. However, innovative dust suppression technologies do exist. These technologies include 1) Polymeric Barrier Systems for 
soil storage piles, 2) water additives that can be applied to road surfaces, and 3) misting nozzles that control water droplet size during the application of dust suppression agents.

Responses were submitted by the following vendors regarding their technologies for structural demolition and/or dust suppression:

- Environmental Engineering Concepts:

Environmental Mist airborne dust spraying system

- The Raring Corporation:

ADS Dust Control

- Atomizing Systems, Inc.:

High Pressure Water Fog Particle Generation

- The Deter Corporation:

Deter Microfoam for Dust Suppression

- U.S. Dismantlement:

Balling Air Jackhammers, Hydraulic Shears, Diamond Saws/Wire Saws, Drilling and Splitting, Manual Methods, Burning, Grinder/Abrasive wheel, GADE/Air Chisel, Sawing, Robot Control Machines, Clamshell Bucket, Grapple Bucket,

Pulverizer/Processor, Blasting/Shape Charges, Torch Cutting/Arc Cutting,

Controlled Collapse, High Pressure Water Blasting, Hydraulic Hammers

- Plantec:

Steel Sheer

- Demolition Technologies Incorporated:

BRISTAR (a non-explosive demolition agent)

The results of the technology survey are presented in Appendix A. 


\section{PROJECT DESCRIPTION}

\subsection{OVERALL'PROJECT GOALS}

The following tasks were conducted as part of this research study:

- Complete literature review of technologies used for structural demolition as well as those used to perform dust suppression;

- Development of a test plan to complete a detailed analysis of dust suppression techniques;

- Selection and acquisition of technologies to perform a detailed analysis of dust suppression techniques;

- Laboratory testing of promising dust suppression technologies; and

- Development of extrapolation factors to be applied to building D\&D for dust suppression techniques.

\subsection{FISCAL YEAR 1996 ACTIVITIES}

The following tasks have been completed as a part of the engineering study:

- Selection and acquisition of dust suppression agents used for site remediation. The selection of the dust suppression agents was based on vendor responses to the literature search survey as well as DOE specifications for dust abatement control. The following dust suppression agents were selected:

* Coherex. This is a water emulsion consisting of petroleum resins that are in suspension in the water. Coherex is a stable, concentrated, nonvolatile water emulsion consisting of 60 percent petroleum resins and 40 percent wetting agent. The resin is not water soluble; therefore, it will not leach out as do the components of most other dust control agents.

* Polymeric Barrier System. This is a water-based, modified latex material. The water mixture consists of 62 percent polymer plus a proprietary mixture and 38 percent water and formaldehyde.

* Water. This is currently the most commonly used agent at DOE facilities.

- The development of a test plan with a detailed analysis of dust suppression techniques. This test plan detailed the procedures to be used, including the type of analysis required, regulatory standards, and milestones to be achieved. The test plan was implemented in order to develop the procedures by which the evaluation of the technologies would proceed. The test plan included the literature review of current baseline and innovative technologies, the experimental design of the evaluation process, and the subsequent development of the 
demolition correlations to be applied to structural demolition. The test plan was followed and completed in accordance with the needs stipulated by DOE and FIU-HCET.

- Laboratory testing of dust suppression methods used at DOE sites. The laboratory testing of the dust suppression methods was conducted at decontamination and decommissioning experimental facilities at FIU-HCET. Each surrogate tested was coated with a dust suppressing agent and demolished. Each surrogate type with a dust agent applied was tested using three different test weights. These weights represented the impact force that would have been applied if the surrogate had fallen from a specified height. Dust was generated from the impact of the weight on the concrete block/surrogate. The resulting dust was sampled via a particle counter. The dust concentration was converted to the number of particles generated in the chamber volume in various particle size intervals.

- Development of correlations to be applied to building D\&D for dust suppression techniques. A correlation was developed between the particle size, impact momentum, and the number of particles per unit logarithmic size interval. Impact momentum is the product of the mass of the impacting body and its velocity. Velocity is a function of the height from which the mass falls. The health and safety effects of the dust during demolition are determined from the concentration readings at different size intervals to evaluate the most effective method for use by $D \& D$ workers during remediation. The correlations developed in association with this project will be applied to building $\mathrm{D} \& \mathrm{D}$ for the prediction of dust generation levels during site remediation. Factors such as applied load and particle distribution will be incorporated into the analysis to determine the number of particles in a unit logarithmic size intervals for load with or without the implementation of a dust suppression method. 


\section{TECHNOLOGY DESCRIPTION}

\subsection{FUNDAMENTAL CONCEPTS}

As more contaminated buildings are being demolished, many non-nuclear technologies are being adapted to the D\&D industry. Even though they are effective in their applications, these technologies generate a considerable amount of dust particles, some of which contain radionuclides.

This project involves a technology assessment for the purpose of evaluating dust suppression techniques. The data resulting from this experimental evaluation of dust suppression techniques have been correlated based on factors such as particle distribution, wall dimensions, and surrogate type. These correlations are mathematical representations of the effects of the various dust suppression methods and their applicability to poured and block concrete wall structures.

The correlations developed will aid in the prediction of dust aerosol levels at remediation sites. The results will be applicable at DOE sites scheduled for remediation or those currently undergoing demolition. The identification of improved structural demolition and dust suppression methods will aid in predicting dust levels for the worst case scenarios, thus allowing site personnel to address the problem of dust inhalation prior to the initiation of D\&D activities.

\subsection{SAFETY AND REGULATORY CONCERNS}

The regulatory policies that apply to the control of dust aerosols during dismantlement are those standards set by :

- National Institute of Occupational Safety and Health (NIOSH), for the abatement of dust aerosols to levels of $<10 \mathrm{mg} / \mathrm{m}^{3}$ for total aerosol mass;

- The Clean Air Act (1990), for air quality to protect public health and welfare and the use of quality standards and criteria for the control of pollutants in the environment; and

- The Clean Water Act (1990), for the control of the levels of effluents containing toxic and hazardous pollutants. 


\section{EXPERIMENTAL INVESTIGATION}

\subsection{EXPERIMENTÁL SYSTEM DESIGN AND APPARATUS}

The experiments to determine the abatement efficiency of the selected agents during demolition were conducted in the Decontamination and Decommissioning Laboratory at FIU-HCET.

The test chamber (with inner dimensions of $4.92 \mathrm{ft} . \times 4.04 \mathrm{ft} . \times 5.97 \mathrm{ft}$.) used for measuring dust particles was constructed of an acrylic glass structure supported by a wood base with an aluminum covering, as shown in Figure 1 (see below). The chamber itself was sealed at the edges with a clear silicon gel. Inlet and outlet ventilation ports were cut into the sides of the test chamber to facilitate the passage of air through the chamber during the wind studies conducted. The ventilation ports were fitted with particulate air filters to allow only clean and filtered air in the chamber. Attached near the top right side of the test chamber was an exhaust fan that allowed for the passage of air from the test environment, simulating the effects of wind during the demolition process. The air inlet port was located on the side opposite the outlet port.

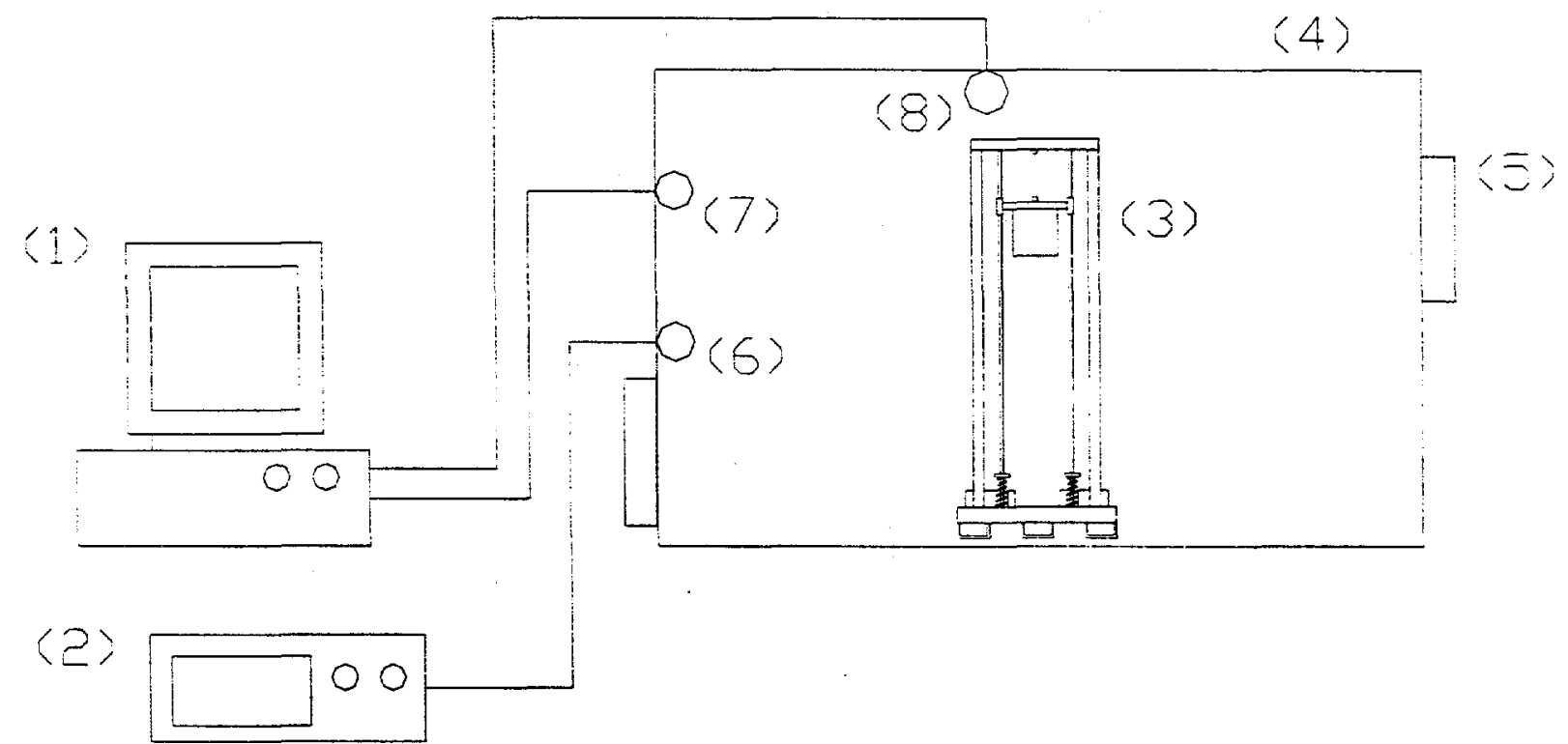

1. Aerosol particle counter

2. Dust monitor

3. Impact machine

4. Test chamber
5. Air blower

6. Institute of Medicine (IOM) dust sampler

7. Aerosol sampling probe (for zero wind configuration)

8. Aerosol sampling probe (for wind configuration)

Figure 1. Schematic representation of the experimental system. 
Inside the chamber, there was an impact device that was composed of a composite structure of various metals such as steel, pig iron, and aluminum. The base of the impact device and superstructure was constructed mainly of aluminum to maintain a minimum weight during the changing of the test weights. The superstructure itself was braced and bolted to the bottom of the structure and the aluminum plate to absorb any moments generated during the release of the test weights. This was carried out primarily to prevent bending forces from transmitting any excessive vibrational forces experienced during impact.

The test weights were made from four-inch square steel rods that were cut into blocks and welded together in order to meet the simulated applied loads for each wall height tested. The experimental test weights were fitted with linear bearings bolted to the side. The bearings ensured that proper linear motion was achieved during the impact of the test weights on the concrete surrogates during simulated demolition conditions. The weights were raised using a hand-operated mechanical winch that was attached to a release lever at the top of test chamber. This release mechanism allowed for the free fall of each test weight.

Three hundred and ten tests were performed as a part of the experimental investigation. The first experimental configuration tested the effects of zero wind conditions on the performance of the dust suppression agents during demolition. The second experimental configuration tested the effects of wind on the performance of the dust suppression agents during demolition. During the course of the experimentation, each of the concrete surrogates used was strategically placed in the center of the impact device base so that the test weights would impact each surrogate at the same location, thus ensuring a consistent experimental procedure during data gathering.

Three impact loads-100,110, and 120 pounds-were applied to the test surrogates during the course of the experiments. The different weights represented different wall heights that are generally encountered during the decommissioning of a facility. The test weights simulated the forces that would be applied when concrete falls from the top position of a concrete wall during structural demolition.

\subsubsection{Instrumentation and Measurements}

For the measurement of particle distribution, a Hiac/Royco MicroAir Model \#5230 airborne particle counter was used. The counter features a built in timing function that permitted it to turn off and on automatically during sampling, depending on the time period selected by the equipment operator. The dust particle distribution was obtained when the dust particles were pulled into the air sampling probe through a diffuser type inlet. The action of the dust particles entering the sampling probe scattered a laser beam light, which triggered a built-in sensor. The sensor then converted the light into electrical pulses whose amplitude was proportional to the particle size. This particular particle counter has the ability to measure particles in eight size channels within the range of $0.3 \mu \mathrm{m}$ to $230 \mu \mathrm{m}$. Experimental readings were taken at $0.3,0.5$, $1.0,5.0,7.0,10.0,15.0$, and $25.0 \mu \mathrm{m}$ to compare the large and small particles generated during the tests. 


\subsubsection{Dust Aerosol Abatement Methods}

Different suppressing agents were evaluated for their effectiveness in dust suppression. These agents - water, water with additives, and polymeric/crusting agents-are used in DOE and in industry. Their performance was compared to the conditions involving no dust suppressing agents.

\subsubsection{No Dust Suppression}

Testing was performed without the application of any dust suppression methods on the concrete surrogates to obtain baseline data for comparison with the dust suppression methods chosen for experimental purposes. Comparison of each method to the baseline data has provided an idea of the magnitude or degree of particulate reduction that was obtained after each dust suppression method was implemented.

\subsubsection{Water Suppression}

The portion of the experiment involving water suppression aimed to assess the effectiveness of the standard spraying methods used in remedial programs for dust control. The volume of water required to reduce the dust emissions to $<10 \mathrm{mg} / \mathrm{m}^{3}$ for total dust control or $5 \mathrm{mg} / \mathrm{m}^{3}$ for respirable dust (dust particles $<10 \mu \mathrm{m}$ in diameter) was assessed. A pressurized water vessel was used with a misting nozzle that helped to control the droplet size of the water during application. Each test surrogate was sprayed while stationary and then placed in the test chamber before impact. This static spreading assisted in the control of dust by means of controlling the droplet diameter or the contact angle, as explained by Mody and Jakhete (1988).

The primary problem with the use of water is that demolition must be performed immediately so as to avoid excessive water runoff that may occur during application. Also, the absorption of water can affect the total amount of dust suppressed during demolition, depending on the porosity of the concrete material. Another factor affecting the use of water is the size of the water droplets applied to the structure; larger-sized droplets tended to fall down the sides of the surrogates as compared to the smaller ones, which normally clung to the material surface and were totally absorbed during application. This behavior is due to the water tension exhibited by the droplet, as described by Mody and Jakhete (1988). This is an important factor when water suppression is used during remediation.

\subsubsection{Water Additive Suppression}

The experimental testing involving water additive suppression was designed to permit a comparison of the effectiveness of water laden with chemical additives versus that of water suppression. The chemical additive used in this experiment was Coherex, a petroleum hydrocarbon in a water emulsion, which aids in the reduction of water tension as a droplet adheres to the surface of a material. Water tension is reduced by controlling either the droplet size or the contact angle through the use of a water additive. 


\subsubsection{Polymeric/Crusting Agent}

Crusting agents or elastic polymers have the potential of decreasing the fraction of the surface that is easily entrained into air. The polymeric barrier material is marketed in solution form. It was applied using a household paint brush.

\subsubsection{Test Surrogate Selection and Preparation}

It was deemed important that the surrogate type and their dimensions closely represent the actual building blocks of the walls destined to be demolished. Furthermore, it was considered that they might require that treatment such as plastering as is done at the block seams in the construction of a wall.

\subsubsection{Surrogate Selection}

Surrogate selection was based on the simulation of the applicable materials present at the DOE facilities scheduled for demolition. Many of these buildings are constructed of hollow concrete block and poured solid concrete structures with other material compositions, though the majority of the material present at each site is concrete. The fact that these two types of structures are the most common in the building construction industry facilitated the acquisition of test surrogates, thus allowing a realistic approach to the experimental procedure.

Experimental samples were prepared to simulate the various structures scheduled for restoration at the numerous sites, that is, the plastered and poured concrete structures. The testing of the concrete surrogates was carried out within a laboratory environment using the selected dust suppression agents. The dimensions of the concrete surrogates were $15 \times 7.5 \times 3.7$ in. and $15 \times$ $7.5 \times 7.5$ in. The former are referred to in this report as the four-inch surrogates, while the latter are deemed the eight-inch surrogates. Two types of concrete surrogates tested within the laboratory were:

- Solid concrete surrogates; and

- Hollow concrete surrogates.

\subsubsection{Four-Inch Hollow Concrete Surrogates}

The selection of the four-inch hollow concrete surrogates was based on the premise that most internal walls are constructed of this type of concrete. To ensure that an accurate demonstration was performed in the laboratory at FIU-HCET, each surrogate was either of the plastered or nonplastered type in order to compare the results of the amount of dust generated for the baseline and actual site conditions. This allowed for a more accurate understanding of the dust generation potential of each material encountered during decontamination and decommissioning.

\subsubsection{Four-Inch Solid Concrete Surrogates}

The selection of the four-inch solid concrete surrogates was based on the premise that most reactor shielding, internal walls, and possibly some external walls, depending on the type of structure, are constructed of this type of concrete material. These test samples were prepared in- 
house because of the unavailability of this type of concrete block. The surrogates were formed in batches of 20 blocks. They were allowed to cure before removal from the casting molds. Care was taken to ensure proper formation during drying. The formation of air pockets during drying was avoided by periodically adding water to the surface of the concrete as it dried, as recommended by the manufacturer. The actual curing time for each surrogate was controlled so as to avoid inconsistencies between batches.

\subsubsection{Eight-Inch Hollow Concrete Surrogates}

The eight-inch hollow concrete surrogates, the final surrogate type tested, were the most important of all the types previously mentioned as this type of block is used mainly for external structural support. These surrogates were selected for testing in the same manner as the four-inch hollow surrogates.

\subsubsection{Non-Plastered Concrete Surrogates}

The selection of the non-plastered concrete surrogates was based on the premise that each dust suppression method must have a baseline criterion with which to compare to actual demolition conditions. That is, each concrete plastered surrogate used during testing was compared to a nonplastered surrogate using the same dust suppression methods and conditions, namely, water suppression, water with an additive, and a polymeric/crusting agent. These were then evaluated for both wind and zero wind conditions to compare each dust suppression method under these two conditions.

\subsubsection{Plastered Concrete Surrogates}

Most wall structures encountered during demolition at DOE sites and elsewhere are made either of four- or eight-inch hollow concrete blocks plastered together. This plastering technique allows for a more rigid structure that can withstand both high winds and other structures that may be attached to the wall (e.g., a roof). Therefore, the simulation of this type of structure was imperative in determining the dust generation potential for each dust suppression agent tested. The four- and eight-inch surrogates were plastered in order to obtain an accurate interpretation of the actual conditions at a remedial site. One-quarter of an inch of mortar was applied at the seam of each concrete block to simulate actual wall structures of this type. Care was taken so as to not over-plaster each surrogate to ensure data reliability.

\subsection{EXPERIMENTAL PROCEDURES}

The experimental procedure consisted of a set of actions for the performance of the investigation and the collection of scientific data. In this experimental study, it was necessary to establish optimal experimental conditions in order to obtain the most consistent and reliable data possible. This was achieved by repeating each test under the exact conditions as each previous test during the course of the experiment. Effects such as infiltration by outside particles were carefully considered. Infiltration was remedied using silicon sealant all around the test chamber, particularly at the seams where the edges of the test chamber were joined together. 


\subsubsection{Procedure for the Zero Wind Measurements}

Prior to data collection, all test equipment was calibrated so as to ensure concise and accurate readings during data collection. Each test surrogate was prepared for demolition by either spraying it with a dust suppression agent such as water or the water/additive mixture or by applying the agent by hand, as in the case of the polymeric/crusting agent. Each test specimen or surrogate was positioned between the superstructure of the impact device, and the test weight was released. The test weight impacted the concrete surrogate, and the force of impact produced the dust aerosol required for sampling.

At the time of release, the particle counter and the dust monitor were engaged. The dust generated from the impact of the weight on the concrete surrogate was sampled utilizing both the particle sampler and the dust monitor. Tests were repeated for data repeatability. Afterward the data collected were downloaded into the personal computer for analysis. The chamber and impact device were thoroughly vacuumed and cleaned before the next set of tests was run to ensure consistent data quality.

\subsubsection{Procedures for Wind Measurements}

The procedures for the collection of data during the wind experiments were similar to those for the zero wind configuration, except that the monitoring ports for particle counting and dust monitoring were located near the exhaust outlet. This location was selected to maximize the collection of the dust particles generated during each test and to minimize any turbulence generated during the release of the test weight. The test surrogate was positioned between the superstructure of the impact device. The blower fan was turned on to simulate wind conditions.

A test was performed every 15 minutes to allow for the stabilization of the free stream air. This allowed for a consistent reading of data and also the ability to clear any entrained particles in the test chamber. Next, the test weight was released, and the impact of the weight on the concrete surrogate generated dust.

At the time of release, the particle counter as well as the dust monitor began sampling the dust generated from the impact of the weight to the concrete surrogate. After the test run was completed, the test was repeated to ensure repeatability, and data were downloaded into the personal computer for analysis. Again, as for the zero wind tests, the test chamber and impact device were thoroughly vacuumed and cleaned before running the next test.

\subsubsection{Experimental Uncertainties}

Experimental uncertainties during the test runs were those that could not be controlled or were beyond the scope of the experiment. Factors such as fracture rate and/or crack propagation were a function of how well the concrete surrogates were made. Test surrogate selection control was kept constant by using a large sample population for each test run. This provided basic quality control for experimental purposes. Even though each surrogate was placed in the same position every time a test was performed, the rate of crack propagation was a factor that was not possible to control. 
Another factor that influenced the quality of the blocks was the drying rate, which depended on the atmospheric conditions. During the zero wind conditions, the dust concentration in the test chamber was non-uniform; particles settled as a result of the influence of gravity. Therefore, the measured concentration and the total number of particles may or may not represent the true concentration. It would be prudent to keep a small circulating fan running in the test chamber to attain uniform concentration. 


\section{EXPERIMENTAL RESULTS}

This experimental study has provided information abcut the particle size distribution, that is, the number of particles generated in various size intervals with and without dust suppression. This information can be used to evaluate the effectiveness of various suppressing agents as well as for the development of a correlation for the dust generated under different experimental conditions.

\subsection{PARTICLE SIZE DISTRIBUTION}

Particles in nature follow log-normal size distribution Mercer (1973). That is, a graph between the number (or fractional number) of particles per unit logarithmic size interval (on the vertical axis) and logarithm of particle size (on the horizontal axis) should exhibit a normal distribution with a number median diameter (NMD) and a geometric standard deviation (GSD).

Figure 2 presents a particle size distribution curve for a no-suppression condition. The horizontal axis shows particle diameter in $\mu \mathrm{m}$. This axis has a natural logarithmic scale. The vertical axis shows the fractional number of particles per unit logarithmic size interval. For example, if $\mathrm{N}$ is the fraction of the total number of particles in the size intervals D1 and D2, the vertical axis represents $\mathrm{N} /(\ln \mathrm{D} 2-\ln \mathrm{D} 1)$. The corresponding point on the horizontal axis is $V(\mathrm{D} 1 \times \mathrm{D} 2)$. The particle size distribution was observed to be bimodal.

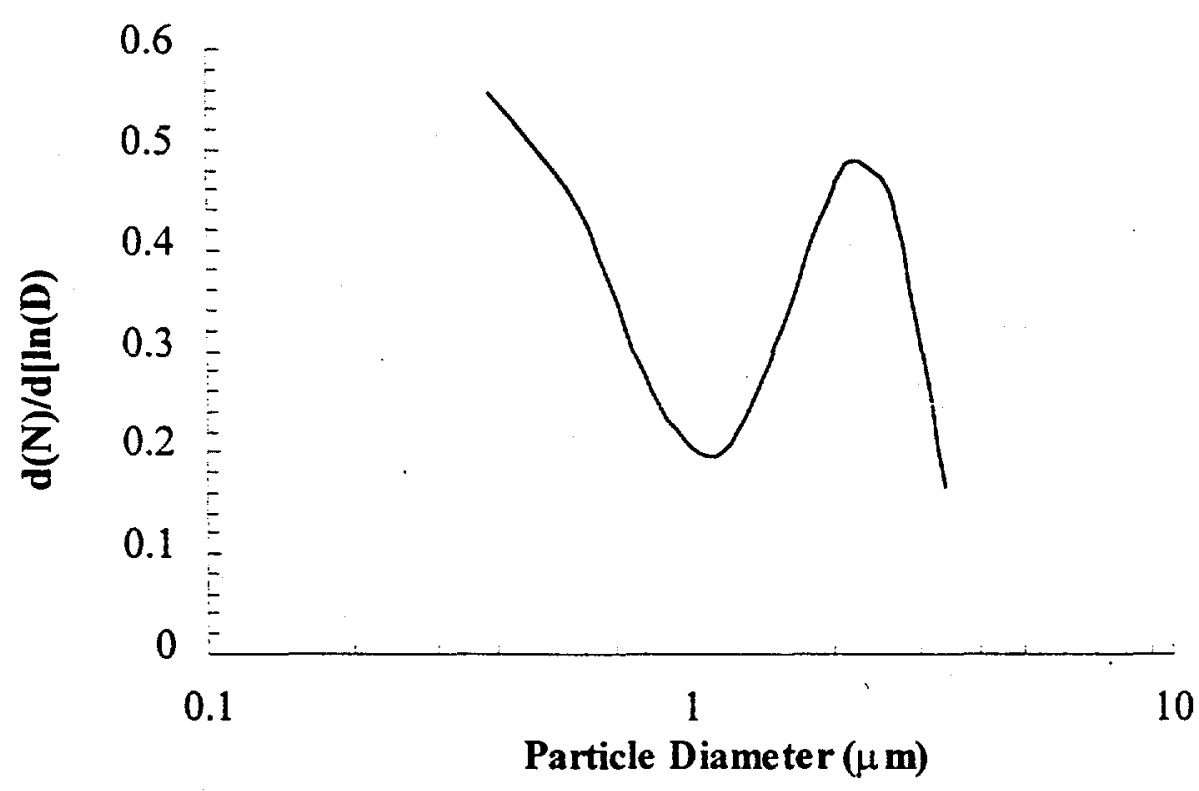

Figure 2. Particle size distribution for the hollow concrete surrogates. No suppression; wind conditions.

The first peak occurred at a particle size of $0.3 \mu \mathrm{m}$ or less. It should be noted that the lower particle size detection limit of the particle counter was $0.3 \mu \mathrm{m}$; therefore, it provided no 
information for particles smaller than $0.3 \mu \mathrm{m}$. Thus, it is not possible to determine the first particle size peak with this instrument. The second peak corresponded to the particle number median diameter of $2.2 \mu \mathrm{m}$ and the geometric standard deviation of 1.5. These values were obtained by fitting a log-normal size distribution to the data by iteration.

\subsection{MASS DISTRIBUTION}

A graph of the mass (or fractional mass) of particles per unit logarithmic size interval and the logarithm of particle size should exhibit a normal distribution with a mass median diameter (MMD) and a GSD. The MMD of an aerosol is related to the NMD by:

$$
\mathrm{MMD}=(\mathrm{NMD})[\exp \{3(\ln (\mathrm{GSD}) \hat{2})\}]
$$

The NMD or the MMD can be determined by plotting the cumulative percentage of the number (or mass) of particles of greater than the stated size against size on the log-probability graph and then finding the size corresponding to 50 percent of the number (or mass). The GSD is obtained by dividing the size corresponding to 16 percent number (or mass) read from this graph by the size corresponding to. 50 percent number (or mass).

Particle mass distribution is obtained by plotting the particle mass per logarithmic size interval against the particle size. The particle mass (per unit size interval) for a given particle size is obtained by multiplying the ordinate values presented in Figure 2 by the cube of the respective diameters.

Figure 3 is a particle size distribution curve by mass. Only one peak appears in this figure inasmuch as small particle diameters make a smaller contribution to the mass. The mode of mass distribution curve appears at about $3 \mu \mathrm{m}$. The MMD can be calculated using Equation (1) or by plotting the fraction of the mass greater than the stated size, that is the cumulative mass, against the particle size on a log- probability graph paper. The MMD for these aerosol particles was determined to be about $3 \mu \mathrm{m}$. 


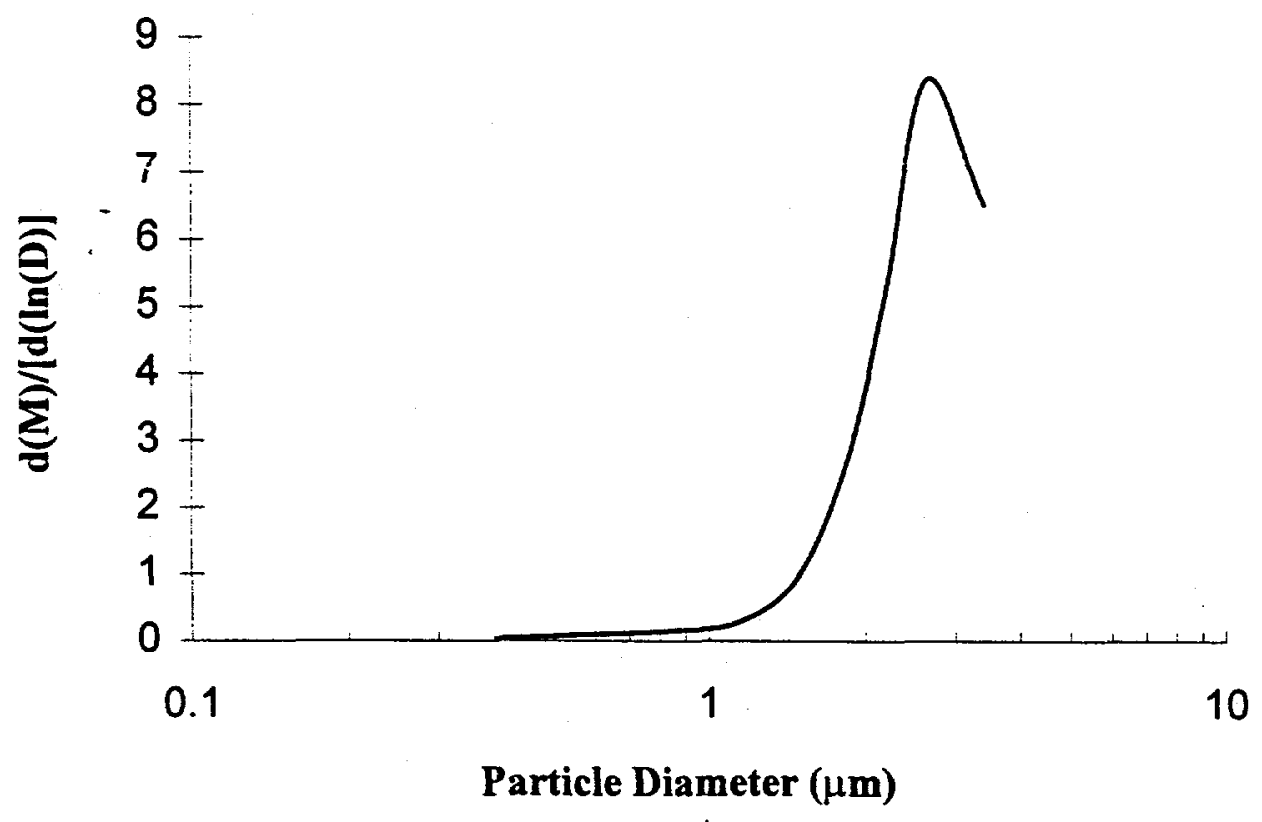

Figure 3. Particle size distribution by mass for the hollow concrete surrogates. No suppression; wind conditions.

\subsection{DUST CONCENTRATION}

The dust concentration is calculated from the total dust particle number or mass (M) sampled and the volume of air sampled. For a flow rate of 1 cubic foot per minute $\left(0.0283 \mathrm{~m}^{3} \mathrm{~min}^{-1}\right)$ and sampling time, $t$, in minutes, the dust concentration, $C_{m}$, is given by:

$$
C_{m}=M /(0.02383)(t)
$$

Alternatively, if the particle concentration in the chamber is known and is uniform, the total number (mass) of particles can be calculated by multiplying the number or mass concentration by the chamber volume.

\subsection{DUST SUPPRESSION}

Table 2 presents the overall effectiveness of different suppressing agents in dust suppression (based on all tests). It has been found that there is no significant difference in the dust suppression capability of one method over the other. However, when a large quantity of an agents is applied, as in the case of the immersion of the blocks in an agent, different methods exhibit different dust suppression capabilities. The FY97 Year-End Report presents the results for the different application conditions for each agent. 
Table 2.

Effectiveness of Dust Suppression Agents Tested

\begin{tabular}{|l|c|c|}
\hline \multicolumn{1}{|c|}{ Dust Suppression Agents } & Dust Suppression (\%) & Relative Standard Deviation (\%) \\
\hline Polymeric Barrier System & 47.7 & 38.4 \\
\hline Coherex & 45.2 & 47.9 \\
\hline Water & 44.9 & 44.4 \\
\hline
\end{tabular}

\subsection{DATA CORRELATIONS}

To predict the total number of particles generated in various particle size ranges for various loads impacting concrete blocks, a correlation between particle size, impact momentum, and number of particle per unit logarithmic size interval was determined. Impact momentum is the product of the mass of the impacting body and its velocity. The velocity itself is a function of the height from which the mass falls.

Three dimensional (3D) correlation curves obtained using the software package TableCurve 3D version 2.0 (Jandel 1993a; 1993b) are presented in Figures 4 through 7 . It can be seen that the generated particle number increases with the impact momentum. For a given impact, particle number varies with size and is the highest for a small size $(\sim 0.3 \mu \mathrm{m})$. Then initially decreasing with size and later increasing until a peak is reached at about $2.2 \mu \mathrm{m}$.

Figures 4 through 7 also provide the expression for $Z$, the number (or mass) of particles per unit logarithmic size interval for impact momenta $X$, in the range 1338 to $1591 \mathrm{lb}$. ft. $\mathrm{s}^{-1}$ (185 to 220 $\mathrm{kg} . \mathrm{m} . \mathrm{s}^{-1}$ ) and particle diameters $(\mathrm{m}), \mathrm{Y}$, above $3 \times 10^{-7} \mathrm{~m}$. These momenta correspond to heights of $17.7 \mathrm{ft}$. to $24.9 \mathrm{ft}$. for a $39.7 \mathrm{lb}$. block, where $\mathrm{a}, \mathrm{b}, \mathrm{c}, \ldots$ are regression constants. The term $\mathrm{r}^{2}$ denotes the coefficient of regression (Jandel, 1993a; 1993b). The closer $r^{2}$ is to unity, the better the correlation. The number of particles for other heights can be obtained by means of direct substitution into the given equation for $Z$.

The mathematical correlations for dust abatement conditions are presented in Appendix B 
Solid Block, No Suppression, Wind

Rank 1 Eqn $316 z=a+b x+c f y+d x^{2}+e y^{2}+f x f y+a x^{3}+h y y^{3}+i x y y^{2}+j x^{2} y$

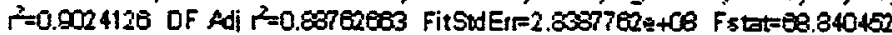

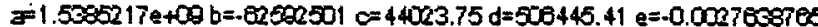

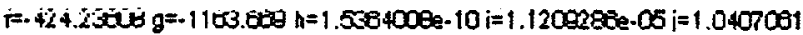

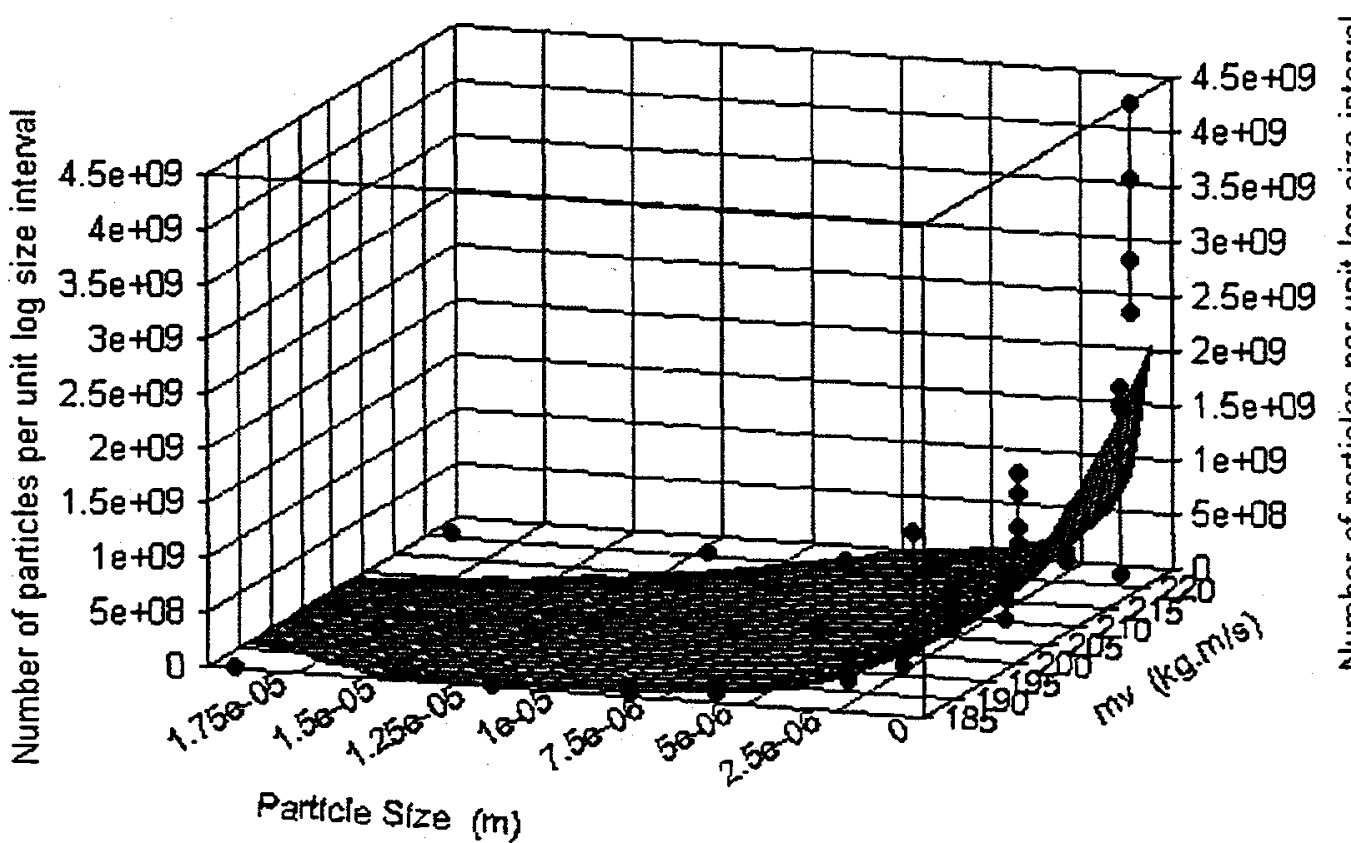

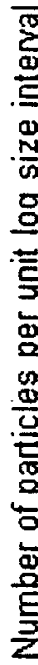

Figure 4. Mathematical correlation for the solid concrete surrogates. No suppression; wind conditions. 


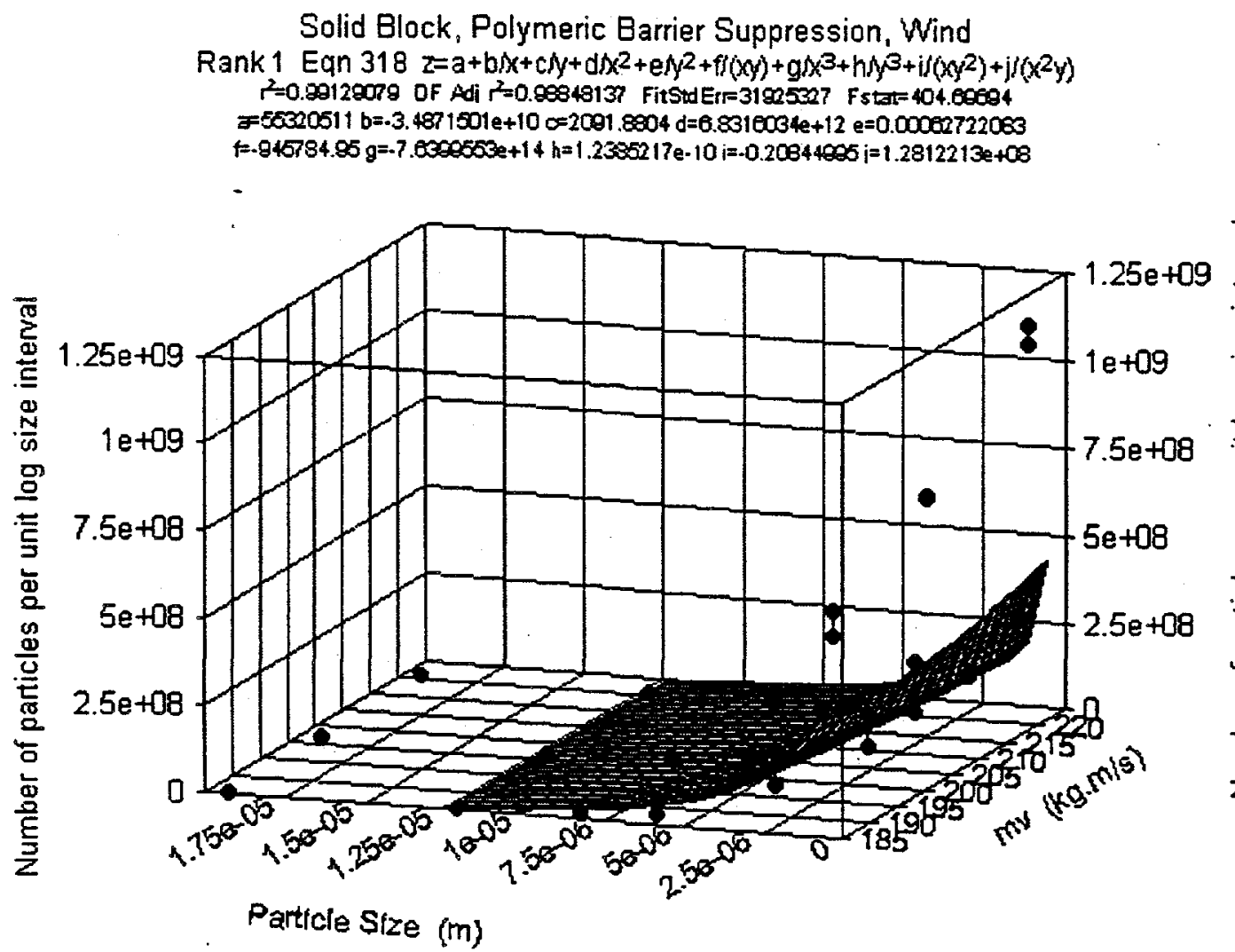

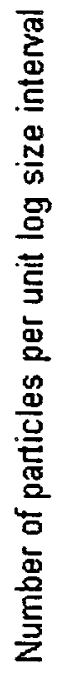

Figure 5. Mathematical correlation for the solid concrete surrogates. Polymeric Barrier System; wind conditions. 
Solid Block, Coherex Additive Suppression, Wind

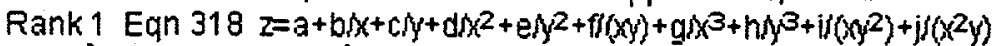

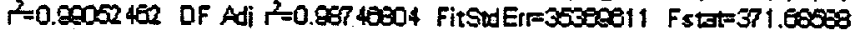

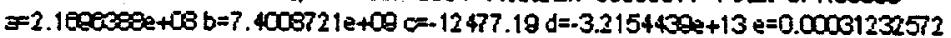

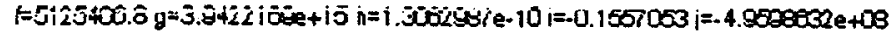

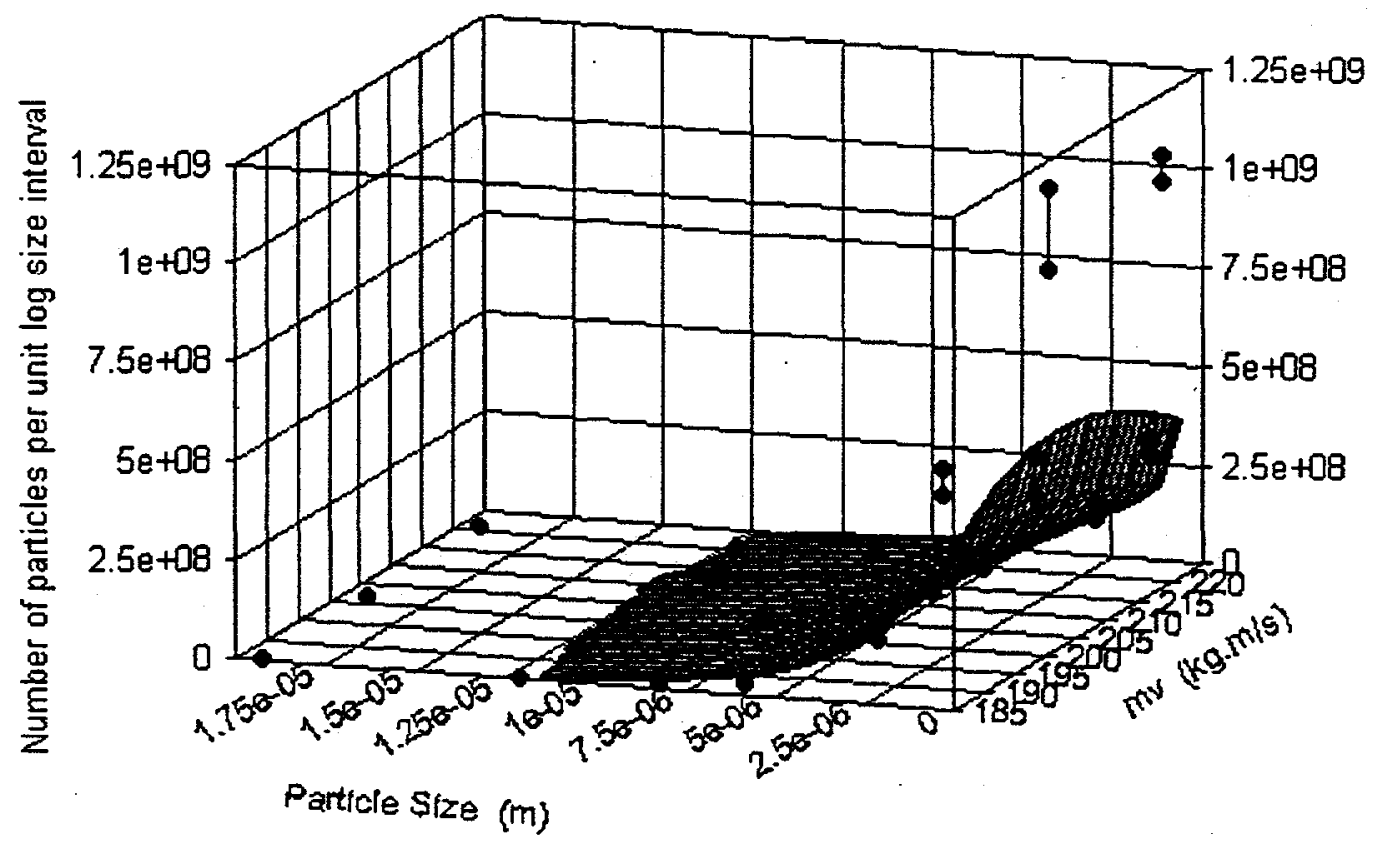

Figure 6. Mathematical correlation for the solid concrete surrogates. Water additive suppression; wind conditions. 
Solid Block, Water Suppression, Wind

Rank 3 Eqn $318 z=a+b f x+c\left(y+d x^{2}+e \gamma^{2}+f f(x y)+g f x^{3}+h / y^{3}+i f\left(x y^{2}\right)+j f\left(x^{2} y\right)\right.$

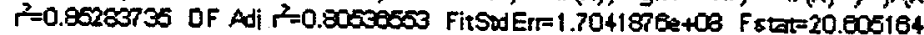

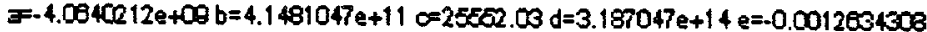

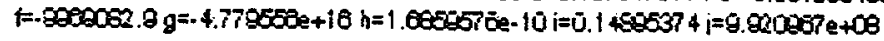

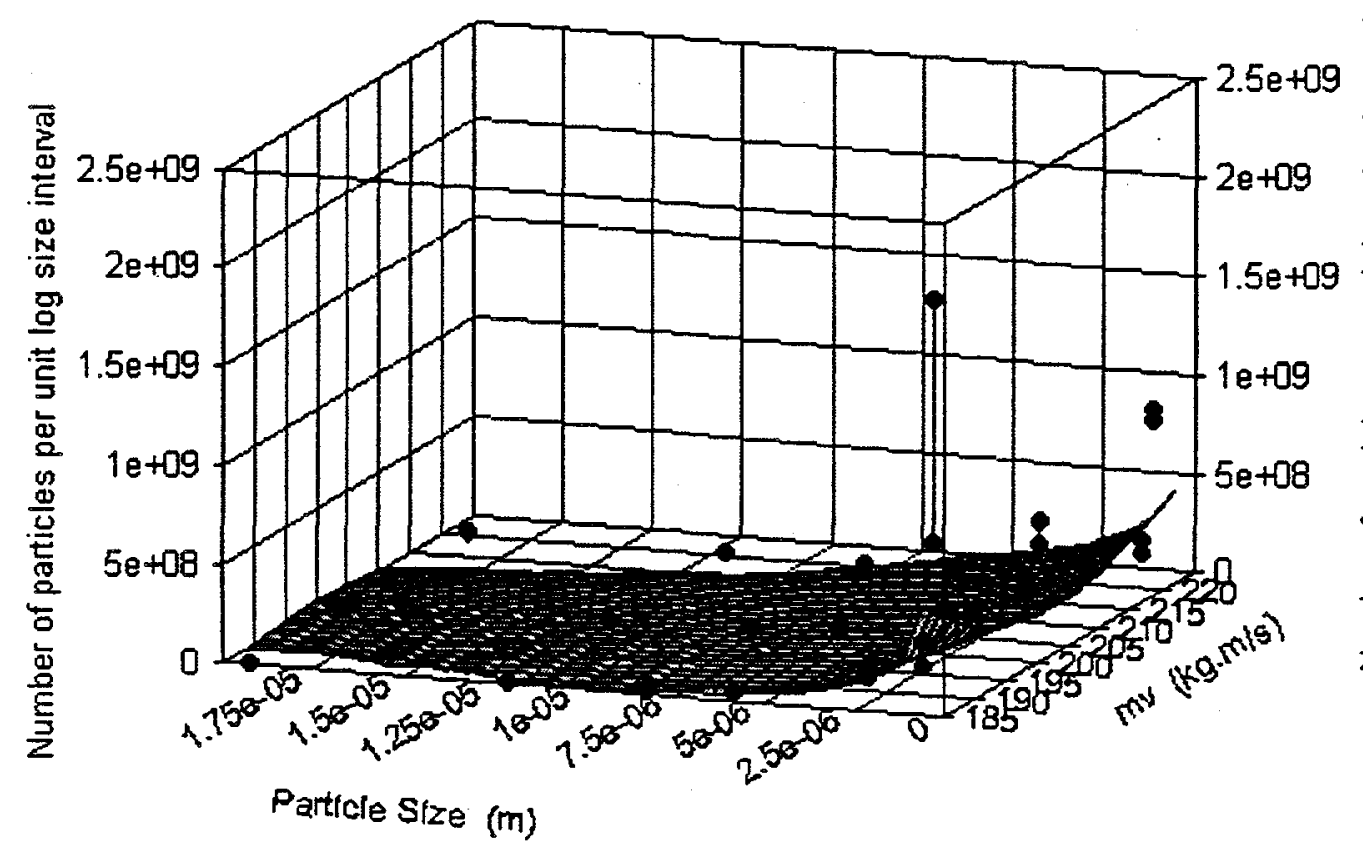

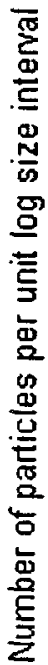

Figure 7. Mathematical correlation for the solid concrete surrogates. Water suppression; wind conditions. 


\section{MAJOR ACCOMPLISHMENTS}

The various project milestones and their status are detailed below:

Milestone 1: Literature Review

Literature Review of technologies that perform structural demolition as well as those that perform dust suppression (completed in FY96);

Milestone 2: DOE Technology Review

Review of DOE and commercial sites related to the end use of the material, contaminant of concern, dust generation, costs, schedule, benefits, and health and safety risks (canceled);

Milestone 3: Develop Test Plan

. Development of a test plan to complete a detailed analysis of dust suppression techniques (completed in FY96);

Milestone 4: Technology Procurement

Selection and acquisition of technologies to perform a detailed analysis of dust suppression techniques (initiated in Fiscal Year 1996; to be completed in FY97);

Milestone 5: Testing of Dust Suppression Equipment

Laboratory testing of promising dust suppression technologies (initiated in FY96;

refinements are to be made and the tests are to be completed in FY97);

Milestone 6: Extrapolation Factors for Building D\&D Dust Suppression

Development of extrapolation factors to be applied to building D\&D for dust suppression techniques (initiated in FY96 to be completed in FY97); and

Milestone 7: Draft and Issue of Final Report

To be completed in FY97. 


\section{CONCLUSIONS}

The preliminary activities that led to the initiation of the experimental testing and the development of the mathematical correlations have been completed. The survey developed by FIU-HCET was forwarded to commercial and the governmental sectors affiliated with the design, development, evaluation, and implementation of demolition and dust suppression technologies for environmental remediation. These governmental agencies included the U.S. Department of Energy's National Research and Development Laboratories.

The information gathered during these preliminary activities has revealed that only a limited number of technologies are available to perform structural demolition at sites scheduled for or currently undergoing restoration are available.

The selection of the dust suppression technologies/agents to be investigated was based on the needs of the sites scheduled for remediation by DOE, site structural material to be demolished, and the responses obtained through the literature search. Once these criteria were met, the experimental design phase and the evaluation of the dust suppression agents were carried out in accordance with the test plan. In general, dust aerosol abatement methods, as the name suggests, are used to suppress fugitive dust particles that are generated by natural or mechanical means. In this investigation, the effectiveness of dust abatement methods was studied using concrete surrogates to simulate actual structural demolition conditions.

Dust abatement was evaluated using water, amended water (water with the addition of the chemical agent Coherex), and a polymeric/crusting agent (Polymeric Barrier System). Overall, it was found that the suppressants tested did indeed meet the requirements of abating dust levels considerably as compared to the use of no abatement methods.

Plain water, the traditional method used to suppress fugitive dust, was found to be comparable to the amended water. In theory, the amended water should increase the dust abatement capacity of plain water by reducing the contact angle (static spreading) or by decreasing the water tension exerted on the surface of the material and by increasing the settling velocity of the water droplets for airborne dust particles (dynamic spreading). For our research purposes, the amended water was statically applied to the material surface rather than dynamically (Mody and Jakhete 1988). In FY97, tests were performed by immersing the surrogates in the Coherex-water mixture as well as in plain water before breaking them. The Coherex-water mixture exhibited better dust suppression capabilities than plain water.

The polymeric/crusting agent tested in this study was somewhat superior to the other methods tested in abating dust levels during the simulated demolition conditions. The crusting agent, a polymeric modified latex agent that comes in a liquid form, was applied on the surface by brush. The polymeric agent dries on the material surface and forms a thin flexible barrier system that reduces the fracture rate of the material during demolition. This experimental investigation verified that the use of the polymeric crusting agent resulted in the reduction of dust particles.

Particle size distribution, an important parameter in determining the deposition of aerosol particles in different compartments of the human respiratory tract, has been determined. Most of the particle mass falls within the respirable size range. In fact, significant fraction of the particle 
mass has been found to be in 2 to $5 \mu \mathrm{m}$ size range. In this size range, there is a large deposition in the pulmonary region of the human respiratory tract. Thus, the dust suppression techniques investigated in the study will be useful for the reduction of lung burden of the workers. 
As has been stated, knowledge of the size distribution of aerosol particles is important in order to predict their deposition in the various compartments of the human respiratory tract. The Hiac/Royco particle counter used for the measurement of particle concentration in various size ranges covers a size range of 0.3 to $230 \mu \mathrm{m}$; thus, it provides no information of the concentration of particles that are less than $0.3 \mu \mathrm{m}$ in diameter. In order to obtain such information as may be needed for size distribution determination, a differential mobility analyzer (DMA) with a condensation nuclei counter can be used. The functional size range of the DMA is 0.005 to $1 \mu \mathrm{m}$. A low-pressure, multistage impactor can be for the determination of the mass (or activity) median aerodynamic diameter of aerosols with lower and upper cut off size of about 0.05 and 10 $\mu \mathrm{m}$, respectively. Although the impactor is a very useful instrument, it is a passive device. It is requires the sample be collected on a substrate and weighed in a micro balance or counted for radioactivity.

The Hiac/Royco particles counter provides on-line particle concentration, and the data can be stored using computer software. It features a maximum of eight size channels beginning at 0.3 $\mu \mathrm{m}$ which can be selected. For this investigation, the particle counter was operated in the size range of 0.3 to $25 \mu \mathrm{m}$. Our experience has shown that only a negligible fraction of particles are larger than $10 \mu \mathrm{m}$ in size. Furthermore, particles above this size are not considered to be a health hazard. However, since the Hiac/Royco counter features only eight channels, at times it is important to select these in narrow size ranges to attain additional information, (e.g., the size distribution or the number of particles in unit size interval). In such cases, it may be useful to conduct measurements in different size ranges with overlapping sizes. This was done for several experiments to determine the particle size distribution. This strategy was adopted for the measurements taken in FY97. This technique facilitated the evaluation of the effectiveness of the dust suppression agents at various particle size ranges. 
Mody, V. and Jakhete, R., 1988, Dust Contro' Handbook, No yes Data Curporation, New Jersey, pp. 54-62:

Jandle Scientific, 1993a, TableCurve 3D6 v1.0 User's Manual, Jandle Scientific, San Rafael, CA.

Jandle Scientific, 1993b, TableCurve 3D6 v1.0, Jandle Scientific, San Rafael, CA.

Mercer, T.T., 1973, Aerosol Technology in Hazard Evaluation, Academic Press, New York. 
Alm, R. R., Hanauska, C. P., Olson, K.A., and Pike, M.T., 1987, The Use of Stabilized Aqueous Foams to Suppress Hazardous Vapors, presented at Hazardous Materials Control Resources Institute, Washington, D.C., November 16-18.

Avallone E. A., and Baumeister III, T., 1987, Mark's Standard Handbook for Mechanical Engineers, McGraw-Hill, NewYork.

Bach, Fr. W., Haferkamp, H., Priesmeyer, U., 1992, "Plasma Arc Cutting Underwater Effects Secondary Waste and Complicates Visual Process Control" $3^{\text {rd }}$ International Conference on Decommissioning Offshore, Onshore Demolition and Nuclear Works, ed.; I L. Whyte, University of Manchester, Institute of Science and Technology, London, pp. 29-35.

Belhadj, A., and Waldron, P., 1992, Demolition of Prestressed Concrete Structures Containing Bonded Tendons, $3^{\text {rd }}$ International Conference on Decommissioning Offshore, Onshore Demolition and Nuclear Works, Manchester, Great Britain, pp. 157-164.

Buchner, S. H. and Lindsell, P., 1992, "Partial Dismantling of a Complex Roof Structure," $3^{\text {rd }}$ International Conference on Decommissioning Offshore, Onshore Demolition and Nuclear Works, ed.; I. L. Whyte, University of Manchester, Institute of Science and Technology, London, pp. 112-116.

Cadle, R. D., 1975, The Measurement of Airborne Particles, John Wiley and Sons, New York.

Cole, H.W., Microfoam for the Control of Source and Fugitive Dust Emissions, DeTer Company, Inc., Burgin, KY.

Cross, J., 1995, "The Decommissioning of the Capenhurst Gaseous Diffusion Plant," Nuclear News, February, pp. $42-44$.

Duce, S.W., Winberg, M.R., and Freeman, A.L., 1989, Basic Radiological Studies Contamination Control Experiments, RAPIC 7034, Idaho National Engineering Laboratory, Idaho Falls, ID.

Freund, H.U. and Fleischer, C.C., 1993, Explosive Cutting Techniques for the Dismantling of Concrete Structures in a Nuclear Power Station Following Decommissioning, EUR14770 Commission of European Communities, Luxembourg.

Gruchow, A., Haferkamp, H., and Bach, W., 1992, Consumable Electrode Water Jet/Oxygen Jet Cutting Technique for the Decommissioning of Fine-Grained Steel Offshore Structures, $3^{\text {rd }}$ International Conference on Decommissioning Offshore, Onshore Demolition and Nuclear Works, ed.; I. L. Whyte, University of Manchester, Institute of Science and Technology, London, pp. 79-85.

Harley, R.A., Hunts, S.E., and Cass, G.R., 1989, "Strategies for the Control of Particulate Air Quality: Least-Cost Solutions Based on Receptor-Oriented Models," Environmental Science and Technology, Vol. 23, No. 8, pp. 1-8. 
Hinds, W. C., 1982, Aerosol Technology: Properties, Behavior, and Measurements of Airborne Particles, John Wiley and Sons, New York.

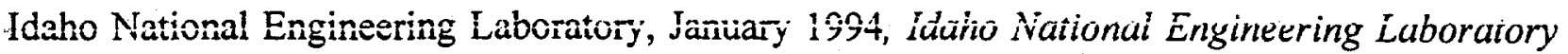
Decontamination and Decommissioning Technology Logic Diagram, EGG-WTB-11104, U.S. Department of Energy.

Kuriyama, O., Koyama, T., and Kikuchi, M., 1983, "Decontamination of Radioactive Metal Surfaces by Plasma Arc Gouging," Nuclear Technology, Vol. 61, pp. 93-99.

Liddle, R., Moss, T., and Horton, P.H., 1993, Rockwell Experience on D\&D of Hot Laboratory, presented at the Environmental Remediation Conference, Augusta, Georgia, October 2428.

Lippy, B., 1996, Excerpt from the American Conference of Governmental Industrial Hygienist Book of Threshold Limit Values, University of Maryland, Environmental Health Education Center, Baltimore.

Lunn, D. J., March 1981, "Nibbling, Laser Cutting and Plasma-Arc Cutting, Tool and Production," pp. 66-69.

Momber, A., 1992, "Energetic Aspects of Mass Concrete Removal Using Plain High Speed Water Jets," $3^{\text {rd }}$ International Conference on Decommissioning Offshore, Onshore Demolition and Nuclear Works, ed., I. L. Whyte, University of Manchester, Institute of Science and Technology, London, pp. 95-101.

Oak Ridge National Laboratory, 1993, Oak Ridge National Laboratory Logic Diagram, ORNL/M-2752, U.S. Department of Energy,

Spittler, F. J., 1995, "Prelude to a Demolition," Civil Engineering, Vol. 65, pp. 52-55.

Thompson, G., 1992, The Design of a Method and Equipment for Decommissioning the WAGR Pressure Vessel and Insulation, Journal of Power and Energy, Vol. 206, No. A2, pp. 125-142.

Trojak, L., 1992, "The Use of Hydraulic Attachments in the Demolition and Decommissioning Applications," 3rd International Conference on Decommissioning Offshore, Onshore Demolition and Nuclear Works, ed., I. L. Whyte, University of Manchester, Institute of Science and Technology, London, pp. 29-35.

U.S. Department of Energy, March 1994, Decommissioning Hàndbook, DOE/EM-0142P, Office of Environmental Restoration, Oak Ridge, TN.

Williams, P. T., Boudreaux, J. F., and Ebadian, M. A., 1996, "Technology Assessment for Improved Structural Demolition and Dust Suppression Techniques," in Proceedings of the International Conference on Nuclear and Hazardous Waste Management, Vol. 3, American Nuclear Society, Inc., La Grange Park, IL, pp. 1962-1965.

Witco Corporation, 1996, Product Fact Sheet, Witco Corporation, Oildale. 
Tables 1 through 28 provide the results of the survey conducted by FIU-HCET to identify the technologies that are currently used in structural demolition/dust suppression.

Table 1.

Environmental Mist Dust Abatement

\begin{tabular}{|l|l|}
\hline Technology Name & Environmental Mist \\
\hline $\begin{array}{l}\text { Technology's Industrial Status } \\
\text { (Current or Innovative) }\end{array}$ & Current \\
\hline Vendor & Environmental Engineering Concepts, Inc. \\
\hline Fax Number & $(619) 322-4341$ \\
\hline Benefits & $\begin{array}{l}\text { Suppression of very small PM-10 particle matter; } \\
\text { uses only 5\% of energy consumed by the filter } \\
\text { bag systems. }\end{array}$ \\
\hline Limitations & $\begin{array}{l}\text { The system needs a continuous supply of water } \\
\text { and power. }\end{array}$ \\
\hline Method & $\begin{array}{l}\text { High pressure water system uses special fog } \\
\text { nozzles with flexible hoses. }\end{array}$ \\
\hline Applicable Building Type & All \\
\hline Theory of Operation & $\begin{array}{l}\text { Increased wetting of the surface by reducing the } \\
\text { droplet diameter and increasing the number of } \\
\text { droplets. Wetting prevents dust from becoming } \\
\text { airborne. }\end{array}$ \\
\hline Previous Product Users & $\begin{array}{l}\text { Mines, reclamation plants, nuclear waste sites, } \\
\text { wood factories, quarries, and asbestos abatement }\end{array}$ \\
\hline
\end{tabular}


Table 2.

ADS Dust Control

\begin{tabular}{|l|l|}
\hline Technology Name & ADS Disi Cültroi \\
\hline $\begin{array}{l}\text { Technology's Industrial Status } \\
\text { (Current or Innovative) }\end{array}$ & Current \\
\hline Vendor & The Raring Corporation \\
\hline Fax Number & $(360) 892-1624$ \\
\hline Benefits & Cost efficiency; simplicity \\
\hline Limitations & None known at this time \\
\hline Method & Agglomeration \\
\hline Applicable Building Type & Unknown \\
\hline Theory of Operation & Agglomeration of dust with water fog \\
\hline Previous Product Users & $\begin{array}{l}\text { Mining, wood products, waste, energy and } \\
\text { cement industries, and others bulk material } \\
\text { handlers and processors. None in the } \\
\text { demolition industry. }\end{array}$ \\
\hline
\end{tabular}

Table 3.

High Pressure Water Fog Particle Generation

\begin{tabular}{|c|c|}
\hline Technology Name & $\begin{array}{l}\text { High Pressure Water Fog Particle } \\
\text { Generation. }\end{array}$ \\
\hline $\begin{array}{l}\text { Technology's Industrial Status } \\
\text { (Current or Innovative) }\end{array}$ & Current \\
\hline Vendor & Atomizing Systems, Inc. \\
\hline Fax Number & (201) 447-6932 \\
\hline Benefits & $\begin{array}{l}\text { No compressed air required; single-feed } \\
\text { line welded pipe system; low energy/low } \\
\text { horsepower ( } 2 \mathrm{HP}) \text {; drives } 140 \text { nozzles. }\end{array}$ \\
\hline Limitations & Clean water system is required. \\
\hline Method & $\begin{array}{l}\text { Dispersion overhead to capture fugitive } \\
\text { dust particles. }\end{array}$ \\
\hline Applicable Building Type & All \\
\hline
\end{tabular}




\section{Table 3.}

High Pressure Water Fog Particle Generation (Continued)

\begin{tabular}{|l|l|}
\hline Theory of Operation & $\begin{array}{l}\text { High pressure water forced through small } \\
\text { ruby orifice fog nozzles produces fine } \\
\text { droplets which capture airborne dust. }\end{array}$ \\
\hline Previous Product Users & $\begin{array}{l}\text { Greenhouse, landfills, trash transfer sites, } \\
\text { theme parks, and wood and paper } \\
\text { manufacturers. Also used for humidity, } \\
\text { dust, and odor control as well as } \\
\text { evaporative cooling, }\end{array}$ \\
\hline
\end{tabular}

Table 4.

Deter Microfoam for Dust Suppression

\begin{tabular}{|l|l|}
\hline Technology Name & Deter Microfoam for Dust Suppression. \\
\hline $\begin{array}{l}\text { Technology's Industrial Status } \\
\text { (Current or Innovative) }\end{array}$ & Current \\
\hline Vendor & The Deter Company, Inc. \\
\hline Fax Number & (606) 748-5262 \\
\hline Benefits & $\begin{array}{l}\text { Deter Microfoam can provide dust } \\
\text { suppression efficiencies as high 99.99\% } \\
\text { without the use of large volumes of water. }\end{array}$ \\
\hline Limitations & None \\
\hline Method & $\begin{array}{l}\text { Compressed air, water, and surfactant are } \\
\text { metered together and foamed; the mixture } \\
\text { is sprayed onto surfaces to be demolished. }\end{array}$ \\
\hline Applicable Building Type & $\begin{array}{l}\text { Steel columns for built-up roofs, concrete } \\
\text { block walls, structural steel frames, and } \\
\text { poured concrete structures. }\end{array}$ \\
\hline Theory of Operation & $\begin{array}{l}\text { Microfoam consists of stable, uniform, } \\
\text { small-sized foam bubbles. Bubble size is } \\
\text { such that < 50 } \mu \text { m particles break the } \\
\text { bubbles, leaving a wet film on the dust } \\
\text { particles, thus preventing them from } \\
\text { becoming airborne. }\end{array}$ \\
\hline Previous Product Users & $\begin{array}{l}\text { Riedel Environmental Services, Corning } \\
\text { Glass, and Dale Electronics. }\end{array}$ \\
\hline
\end{tabular}


Table 5.

Standard Balling

\begin{tabular}{|l|l|}
\hline Technology Name & Standaru Bailing \\
\hline $\begin{array}{l}\text { Technology's Industrial Status } \\
\text { (Current or Innovative) }\end{array}$ & Current \\
\hline Vendor & U.S. Dismantlement \\
\hline Fax Number & (312) 685-8378 \\
\hline Benefits & $\begin{array}{l}\text { Very efficient in the time limitations } \\
\text { required to wreck applicable structure. }\end{array}$ \\
\hline Limitations & $\begin{array}{l}\text { Poor dust control; inability to control } \\
\text { wrecking ball effectively; medium to high } \\
\text { vibration levels. }\end{array}$ \\
\hline Method & $\begin{array}{l}\text { Steel wrecking ball is attached to steel } \\
\text { cabling on an excavator. }\end{array}$ \\
\hline Applicable Building Type & $\begin{array}{l}\text { All types (i.e., steel columns for built-up } \\
\text { roofs, concrete block walls, structural steel } \\
\text { frame, and poured concrete structures). }\end{array}$ \\
\hline Theory of Operation & $\begin{array}{l}\text { Heavy steel ball is raised to a } \\
\text { predetermined height using steel cabling } \\
\text { and is allowed to drop under the effect of } \\
\text { gravity. The impact force produced by the } \\
\text { ball demolishes the structure. }\end{array}$ \\
\hline Previous Product Users & $\begin{array}{l}\text { Wrecking companies, e.g., Cleveland } \\
\text { Wrecking. }\end{array}$ \\
\hline
\end{tabular}


Table 6.

Standard Bucket Technology

\begin{tabular}{|l|l|}
\hline Technology Name & Standard Bucket \\
\hline $\begin{array}{l}\text { Technology's Industrial Status } \\
\text { (Current or Innovative) }\end{array}$ & Current \\
\hline Vendor & U.S. Dismantlement \\
\hline Fax Number & $(312) 685-8378$ \\
\hline Benefits & $\begin{array}{l}\text { Efficient in the demolition of small } \\
\text { structural members; cost savings is greatly } \\
\text { reduced when used on smaller structural } \\
\text { members. }\end{array}$ \\
\hline Limitations & $\begin{array}{l}\text { Poor dust control; spray attachment may be } \\
\text { required; control of attachment during } \\
\text { demolition operations is not very good. }\end{array}$ \\
\hline Method & $\begin{array}{l}\text { Performs the demolition of structures using } \\
\text { a bucket attached to an excavator. }\end{array}$ \\
\hline Applicable Building Type & $\begin{array}{l}\text { Small structural steel, concrete, and built- } \\
\text { up roof-type structures. }\end{array}$ \\
\hline Theory of Operation & Drop heavy steel ball to crush building. \\
\hline Previous Product Users & $\begin{array}{l}\text { Wrecking companies, e.g., Cleveland } \\
\text { Wrecking. }\end{array}$ \\
\hline
\end{tabular}

Table 7.

Diamond Saws/Wire Saws

\begin{tabular}{|l|l|}
\hline Technology Name & Diamond Saws/Wire Saws \\
\hline $\begin{array}{l}\text { Technology's Industrial Status } \\
\text { (Current or Innovative) }\end{array}$ & Current \\
\hline Vendor & U.S. Dismantlement \\
\hline Fax Number & $(312) 685-8378$ \\
\hline Benefits & Simple system \\
\hline Limitations & None \\
\hline Method & $\begin{array}{l}\text { The saws cut by an abrasive method wet or } \\
\text { dry; the choice is based on the material to } \\
\text { be cut and the type of diamond wire used. }\end{array}$ \\
\hline
\end{tabular}


Table 7.

Diamond Saws/Wire Saws (Continued) .

\begin{tabular}{|l|l|}
\hline Applicabie Duilding Type & $\begin{array}{l}\text { Cutting doorways in reinforced concrete } \\
\text { walls or cutting complex structures. }\end{array}$ \\
\hline Theory of Operation & $\begin{array}{l}\text { The saws consist of a steel cable onto } \\
\text { which diamond-coated steel beads have } \\
\text { been threaded, spaced by plastic injection } \\
\text { molding }\end{array}$ \\
\hline Previous Product Users & U.S. DOE sites \\
\hline
\end{tabular}

Table 8.

Cutter/Crushers

\begin{tabular}{|l|l|}
\hline Technology Name & Cutter/Crushers \\
\hline $\begin{array}{l}\text { Technology's Industrial Status } \\
\text { (Current or Innovative) }\end{array}$ & Current \\
\hline Vendor & U.S. Dismantlement \\
\hline Fax Number & $(312) 685-8378$ \\
\hline Benefits & $\begin{array}{l}\text { Can remove small and large structural } \\
\text { members. }\end{array}$ \\
\hline Limitations & Limitations due to the size of the excavator. \\
\hline Method & Machine mounted jaw attachments. \\
\hline Applicable Building Type & Structural steel and concrete. \\
\hline Theory of Operation & $\begin{array}{l}\text { Tool is mounted onto the back hoe or arm } \\
\text { of a conventional hydraulic excavator. The } \\
\text { jaws are deployed to cut through concrete } \\
\text { and steel structural members. }\end{array}$ \\
\hline Previous Product Users & JCB Hydropower \\
\hline
\end{tabular}


Table 9.

Hydraulic Shears

\begin{tabular}{|l|l|}
\hline Technology Name & Hydraulic Shears \\
\hline $\begin{array}{l}\text { Technology's Industrial Status } \\
\text { (Current or Innovative) }\end{array}$ & Current \\
\hline Vendor & U.S. Dismantlement \\
\hline Fax Number & $(312) 685-8378$ \\
\hline Benefits & $\begin{array}{l}\text { Ability to both cut large and small steel } \\
\text { members. }\end{array}$ \\
\hline Limitations & None \\
\hline Method & $\begin{array}{l}\text { Cut steel members using a hydraulic } \\
\text { attachment on existing heavy duty } \\
\text { construction equipment. }\end{array}$ \\
\hline Applicable Building Type & Structural steel members. \\
\hline Theory of Operation & Hydraulic cutting \\
\hline Previous Product Users & U.S. DOE sites \\
\hline
\end{tabular}


Table 10.

Steel Shear

\begin{tabular}{|l|l|}
\hline Technology Name & Steel Shear \\
\hline $\begin{array}{l}\text { Technology's Industrial Status } \\
\text { (Current or Innovative) }\end{array}$ & Current \\
\hline Vendor Name & Plantec \\
\hline Fax Number & 441524263040 \\
\hline Benefits' & Severs large steel structural members. \\
\hline Limitations & $\begin{array}{l}\text { Limitations based on size of excavator for } \\
\text { shear attachment }\end{array}$ \\
\hline Method & Hydraulic shears \\
\hline Applicable Building Type & Structural steel \\
\hline Theory of Operation & $\begin{array}{l}\text { Uses hydraulic shears are mounted onto the } \\
\text { hydraulic manipulator and excavator arms } \\
\text { to facilitate dismantling of main building } \\
\text { superstructure of steel-framed buildings. }\end{array}$ \\
\hline Previous Product Users & U.S. DOE sites \\
\hline
\end{tabular}

Table 11.

Grinder/Abrasive Wheel

\begin{tabular}{|l|l|}
\hline Technology Name & Grinder/Abrasive Wheel \\
\hline $\begin{array}{l}\text { Technology's Industrial Status } \\
\text { (Current or Innovative) }\end{array}$ & Current \\
\hline Vendor & U.S. Dismantlement \\
\hline Fax Number & $(312) 685-8378$ \\
\hline Benefits & Low dust aerosol levels \\
\hline Limitations & $\begin{array}{l}\text { Because the diameter decreases as the work } \\
\text { progresses, this process is limited to cutting } \\
\text { thin sections. }\end{array}$ \\
\hline Method & $\begin{array}{l}\text { Rotating abrasive wheel attached to an } \\
\text { electrical motor }\end{array}$ \\
\hline Applicable Building Type & Thin, metallic structural members \\
\hline
\end{tabular}


Table 11.

Grinder/Abrasive Wheel (Continued)

\begin{tabular}{|l|l|}
\hline Theory of Operation & $\begin{array}{l}\text { Uses a soft abrasive disc to cut into the } \\
\text { work piece; the disc erodes as the work } \\
\text { piece is cut. }\end{array}$ \\
\hline Previous Product Users & U.S. DOE sites \\
\hline
\end{tabular}

Table 12.

Controlled Burning

\begin{tabular}{|c|c|}
\hline Technology Name & Controlled Burning \\
\hline $\begin{array}{l}\text { Technology's Industrial Status } \\
\text { (Current or Innovative) }\end{array}$ & Current \\
\hline Vendor & U.S. Dismantlement \\
\hline Fax Number & (312) 685-8378 \\
\hline Benefits & $\begin{array}{l}\text { Easy dismantlement, low capital cost, and } \\
\text { less waste generation due to burning } \\
\text { process }\end{array}$ \\
\hline Limitations & $\begin{array}{l}\text { High smoke inhalation by workers; poor } \\
\text { dust generation control though combustion } \\
\text { process. All friable materials such as } \\
\text { asbestos and highly flammable materials } \\
\text { must be removed from structure prior to } \\
\text { burning. }\end{array}$ \\
\hline Method & Setting existing structure on fire. \\
\hline Applicable Building Type & $\begin{array}{l}\text { Wooden structures and nonprocess } \\
\text { buildings such as warehouses and office } \\
\text { buildings. }\end{array}$ \\
\hline Theory of Operation & Demolition through the use of fire. \\
\hline Previous Product Users & U.S. DOE sites \\
\hline
\end{tabular}


Table 13.

Manual Method

\begin{tabular}{|l|l|}
\hline Technology Nâñe & Mlanual Múthod \\
\hline $\begin{array}{l}\text { Technology's Industrial Status } \\
\text { (Current or Innovative) }\end{array}$ & Current \\
\hline Vendor & U.S. Dismantlement \\
\hline Fax Number & $312-685-8378$ \\
\hline Benefits & $\begin{array}{l}\text { Effective on structures with high asbestos } \\
\text { layer contamination. }\end{array}$ \\
\hline Limitations & Labor intensive \\
\hline Method & $\begin{array}{l}\text { Use of labor force to remove existing } \\
\text { materials from site facilities. }\end{array}$ \\
\hline Applicable Building Type & $\begin{array}{l}\text { Limited to structures with low concrete } \\
\text { material composition. }\end{array}$ \\
\hline Theory of Operation & $\begin{array}{l}\text { Use of site or contracted personnel to } \\
\text { perform demolition tasks. }\end{array}$ \\
\hline Previous Product Users & $\begin{array}{l}\text { U.S. DOE sites, e.g., Idaho, Argonne, } \\
\text { Chicago, and Fernald. }\end{array}$ \\
\hline
\end{tabular}

Table 14.

GADE/Air Chisel

\begin{tabular}{|l|l|}
\hline Technology Name & Gade/Air Chisel \\
\hline $\begin{array}{l}\text { Technology's Industrial Status } \\
\text { (current or innovative) }\end{array}$ & Current \\
\hline Vendor & U.S. Dismantlement \\
\hline Fax Number & $(312) 685-8378$ \\
\hline Benefits & $\begin{array}{l}\text { Manual, semi-remote, or remote } \\
\text { deployment of technology. }\end{array}$ \\
\hline Limitations & $\begin{array}{l}\text { Air supply required at site facility; tools } \\
\text { can be noisy if used in confined spaces; } \\
\text { excessive vibration can be transmitted to } \\
\text { surrounding structures and the deployment } \\
\text { system. }\end{array}$ \\
\hline
\end{tabular}


Table 14.

GADE/Air Chisel (Continued)

\begin{tabular}{|l|l|}
\hline Method & $\begin{array}{l}\text { Mechanically powered chisels are used to } \\
\text { cut into concrete material. }\end{array}$ \\
\hline Applicable Building Type & $\begin{array}{l}\text { Very effective on normal concrete but less } \\
\text { so when reinforcing is present. }\end{array}$ \\
\hline Theory of Operation & See "Method" \\
\hline Previous Product Users & JCB Hydropower; U.S. DOE sites. \\
\hline
\end{tabular}

\section{Table 15.}

Sawing

\begin{tabular}{|c|c|}
\hline Technology Name & Sawing \\
\hline $\begin{array}{l}\text { Technology's Industrial Status } \\
\text { (Current or Innovative) }\end{array}$ & Current \\
\hline Vendor & U.S. Dismantlement \\
\hline Fax Number & (312) $685-8378$ \\
\hline Benefits & $\begin{array}{l}\text { Used when the disturbance of the } \\
\text { surrounding material must be kept to a } \\
\text { minimum; dust is kept at a minimum using } \\
\text { a water spray. Low vibration, low shock, } \\
\text { and relatively quiet. }\end{array}$ \\
\hline Limitations & $\begin{array}{l}\text { Depend on the type of saw used (flat, } \\
\text { circular, diamond, etc.), the space available } \\
\text { for use of the saw, and the material is } \\
\text { hardness. }\end{array}$ \\
\hline Method & $\begin{array}{l}\text { Rotating blade housed in a protective shield } \\
\text { is used for structural removal during } \\
\text { structural demolition. }\end{array}$ \\
\hline
\end{tabular}


Table 15.

Sawing (Continued)

\begin{tabular}{|l|l|}
\hline Applicable Builüing Type & $\begin{array}{l}\text { Concrete structures up to } 3 \mathrm{ft} \text {. thick as weii } \\
\text { as other structural materials such as I- } \\
\text { beams, plastics, and other composite } \\
\text { materials, depending on the saw type. }\end{array}$ \\
\hline Theory of Operation & $\begin{array}{l}\text { Operation varies according to the saw type } \\
\text { and the application. }\end{array}$ \\
\hline Previous Product Users & $\begin{array}{l}\text { Nuclear power plant decommissioning; } \\
\text { U.S. DOE sites }\end{array}$ \\
\hline
\end{tabular}

Table 16.

Robot Control Machines

\begin{tabular}{|l|l|}
\hline Technology Name & Robot Control Machines \\
\hline $\begin{array}{l}\text { Technology's Industrial Status } \\
\text { (Current or Innovative) }\end{array}$ & Current \\
\hline Vendor & U.S. Dismantlement \\
\hline Fax Number & $(312) 685-8378$ \\
\hline Benefits & $\begin{array}{l}\text { Removes any radiation exposure risks to } \\
\text { workers in highly contaminated areas } \\
\text { through the use of remote operation. }\end{array}$ \\
\hline Limitations & $\begin{array}{l}\text { Limited robotic manipulator movement } \\
\text { capabilities; immediate response to tasks or } \\
\text { problems is nonexistent; rehearsal required } \\
\text { in order to perform tasks in hostile } \\
\text { environments. Also, structural material } \\
\text { removal is limited to manipulator weight } \\
\text { capacity. }\end{array}$ \\
\hline Method & $\begin{array}{l}\text { Remote control device replaces humans in } \\
\text { highly contaminated areas during facility } \\
\text { demolition or decontamination. }\end{array}$ \\
\hline Applicable Building Type & All \\
\hline Theory of Operation & $\begin{array}{l}\text { Remotely controlled device performs } \\
\text { manual tasks in high radiation areas. }\end{array}$ \\
\hline Previous Product Users & U.S. DOE sites, e.g., CP-5 reactor. \\
\hline
\end{tabular}


Table 17.

Bristar

\begin{tabular}{|l|l|}
\hline Technology Name & Bristar \\
\hline $\begin{array}{l}\text { Technology's Industrial Status } \\
\text { (Current or Innovative) }\end{array}$ & Current \\
\hline Vendor & Demolition Technologies, Incorporated \\
\hline Fax Number & $(334) 382-7548$ \\
\hline Benefits & $\begin{array}{l}\text { No dust, gas, ground vibration, or noise } \\
\text { generation; good handling characteristics in } \\
\text { terms of application; strong adhesion and } \\
\text { friction resistance when applied in the } \\
\text { proper manner; chemically safe substance. }\end{array}$ \\
\hline Limitations & $\begin{array}{l}\text { Protective coating is required during } \\
\text { mixing and application due to powder } \\
\text { form. }\end{array}$ \\
\hline Method & A nonexplosive demolition agent. \\
\hline Applicable Building Type & Concrete structures \\
\hline Theory of Operation & $\begin{array}{l}\text { Bristar is mixed with appropriate quantity } \\
\text { of water and poured into cylindrical holes } \\
\text { drilled in concrete or rock. Bristar cracks } \\
\text { the matter to be demolished, which can } \\
\text { then be easily removed using a pick } \\
\text { breaker, pneumatic breaker, excavator, etc. }\end{array}$ \\
\hline Previous Product Users & $\begin{array}{l}\text { Brown \& Root USA, Inc.; Muskogee } \\
\text { Bridge Company; Ebasco Service, Inc. }\end{array}$ \\
\hline
\end{tabular}


Table 18.

Clamshell Bucket

\begin{tabular}{|l|l|}
\hline Technology Name & Clamshell Bucket \\
\hline $\begin{array}{l}\text { Technology's Industrial Status } \\
\text { (Current or Innovative) }\end{array}$ & Current \\
\hline Vendor & U.S. Dismantlement \\
\hline Fax Number & $(312) 685-8378$ \\
\hline Benefits & $\begin{array}{l}\text { Large-scale structural demolition and } \\
\text { debris removal. }\end{array}$ \\
\hline Limitations & $\begin{array}{l}\text { Space constraints are related to the size of } \\
\text { the building to be demolished and the } \\
\text { machine which uses this attachment. Also, } \\
\text { the control of dust is very poor during } \\
\text { demolition. }\end{array}$ \\
\hline Method & $\begin{array}{l}\text { Large scooping device attached to remove } \\
\text { structural debris after structural demolition. }\end{array}$ \\
\hline Applicable Building Type & $\begin{array}{l}\text { Structural debris removal of concrete or } \\
\text { structural steel. }\end{array}$ \\
\hline Theory of Operation & $\begin{array}{l}\text { Large mechanical jaw with scooping } \\
\text { capabilities is attached to a mobile vehicle } \\
\text { for the removal of structural debris and/or } \\
\text { demolition. }\end{array}$ \\
\hline Previous Product Users & $\begin{array}{l}\text { Wrecking companies, e.g. Cleveland } \\
\text { Wrecking; U.S. DOE sites; LaBounty } \\
\text { Manufacturing, Incorporated. }\end{array}$ \\
\hline
\end{tabular}

Table 19.

Grapple Bucket

\begin{tabular}{|l|l|}
\hline Technology Name & Grapple Bucket \\
\hline $\begin{array}{l}\text { Technology's Industrial Status } \\
\text { (Current or Innovative) }\end{array}$ & Current \\
\hline Vendor & U.S. Dismantlement \\
\hline Fax Number & $(312) 685-8378$ \\
\hline
\end{tabular}


Table 19.

Grapple Bucket (Continued)

\begin{tabular}{|l|l|}
\hline Benefits & $\begin{array}{l}\text { Mechanical device used for quick land } \\
\text { clearing or scrap recycling. }\end{array}$ \\
\hline Limitations & $\begin{array}{l}\text { Loading capabilities mainly but can be } \\
\text { applied to light structural demolition such } \\
\text { as built-up roofs. Not recommended for } \\
\text { radioactive structures. }\end{array}$ \\
\hline Method & $\begin{array}{l}\text { All purpose tool for demolition and } \\
\text { materials handling. }\end{array}$ \\
\hline Applicable Building Type & $\begin{array}{l}\text { Mainly used for loading structural rebars } \\
\text { and crushed concrete debris. }\end{array}$ \\
\hline Theory of Operation & $\begin{array}{l}\text { Large mechanical scooping jaw-like device } \\
\text { which aids in the removal of structural } \\
\text { debris. }\end{array}$ \\
\hline Previous Product Users & $\begin{array}{l}\text { Wrecking companies, e.g. Cleveland } \\
\text { Wrecking; U.S. DOE sites; LaBounty } \\
\text { Manufacturing, Incorporated. }\end{array}$ \\
\hline
\end{tabular}

Table 20.

Pulverizer/Processor

\begin{tabular}{|l|l|}
\hline Technology Name & Pulverizer/Processor \\
\hline $\begin{array}{l}\text { Technology's Industrial Status } \\
\text { (Current or Innovative) }\end{array}$ & Current \\
\hline Vendor & U.S. Dismantlement \\
\hline Fax Number & $(312) 685-8378$ \\
\hline Benefits & $\begin{array}{l}\text { Ability to crush concrete in order to reduce } \\
\text { the size of concrete blocks for disposal and } \\
\text { facilitate the removal of any rebars present. }\end{array}$ \\
\hline Limitations & $\begin{array}{l}\text { Space constraint is a function of the size of } \\
\text { the back hoe. }\end{array}$ \\
\hline Method & $\begin{array}{l}\text { The jaws are deployed to crush blocks of } \\
\text { concrete following removal from the main } \\
\text { structures of facilities. }\end{array}$ \\
\hline
\end{tabular}


Table 20.

Pulverizer/Processor (Continued)

\begin{tabular}{|l|l|}
\hline Applicable Bliiding Type & $\begin{array}{l}\text { Mainily concreit struciures, bur } \\
\text { applicability to other demolition purposes } \\
\text { is also feasible. }\end{array}$ \\
\hline Theory of Operation & $\begin{array}{l}\text { Machines with mounted jaws which fit } \\
\text { onto the back hoe or arm of a conventional } \\
\text { hydraulic excavator. }\end{array}$ \\
\hline Previous Product Users & JCB Hydropower \\
\hline
\end{tabular}

Table 21.

Blasting/Shape Charges

\begin{tabular}{|c|c|}
\hline Technology Name & Blasting/Shape Charges \\
\hline $\begin{array}{l}\text { Technology's Industrial Status } \\
\text { (Current or Innovative) }\end{array}$ & Current \\
\hline Vendor & U.S. Dismantlement \\
\hline Fax Number & (312) $685-8378$ \\
\hline Benefits & $\begin{array}{l}\text { Charges can be set manually or with } \\
\text { remotely operated tools. }\end{array}$ \\
\hline Limitations & $\begin{array}{l}\text { Extensive explosive demolition experience } \\
\text { required. }\end{array}$ \\
\hline Method & Explosive cutting technique. \\
\hline Applicable Building Type & All \\
\hline Theory of Operation & $\begin{array}{l}\text { The process is based upon the Munroe } \\
\text { Effect; it uses directed shock waves } \\
\text { together with explosive decomposition and } \\
\text { the metal fragments from the explosive's } \\
\text { sheathing material. }\end{array}$ \\
\hline Previous Product Users & Explosive Technology, Inc.; U.S. DOE \\
\hline
\end{tabular}


Table 22.

Torch Cutting/Arc Cutting

\begin{tabular}{|l|l|}
\hline Technology Name & Torch Cutting/Arc Cutting \\
\hline $\begin{array}{l}\text { Technology's Industrial Status } \\
\text { (Current or Innovative) }\end{array}$ & Current \\
\hline Vendor & U.S. Dismantlement \\
\hline Fax Number & $(312) 685-8378$ \\
\hline Benefits & $\begin{array}{l}\text { Can be used in wet and dry working } \\
\text { conditions; some torches are portable. }\end{array}$ \\
\hline Limitations & Gas and electrical supply. \\
\hline Method & Plasma, electrical, or gas cutting. \\
\hline Applicable Building Type & Structural steel members. \\
\hline Theory of Operation & $\begin{array}{l}\text { Uses a hot flame or gaseous or plasma arc } \\
\text { to remove structural members from } \\
\text { existing site facilities. }\end{array}$ \\
\hline Previous Product Users & \begin{tabular}{l} 
U.S. DOE sites \\
\hline
\end{tabular}
\end{tabular}

Table 23.

Controlled Collapse

\begin{tabular}{|l|l|}
\hline Technology Name & Controlled Collapse \\
\hline $\begin{array}{l}\text { Technology's Industrial Status (current or } \\
\text { innovative) }\end{array}$ & Current \\
\hline Vendor Name & U.S. Dismantlement \\
\hline Fax Number & $(312) 685-8378$ \\
\hline Benefits & $\begin{array}{l}\text { Demolition equipment is kept to a } \\
\text { minimum during remediation. }\end{array}$ \\
\hline Limitations & $\begin{array}{l}\text { Poor dust control due to falling action of } \\
\text { structural material. }\end{array}$ \\
\hline Method & $\begin{array}{l}\text { Structure is pulled or pushed down by } \\
\text { mechanical means. }\end{array}$ \\
\hline Applicable Building Type & $\begin{array}{l}\text { Structural steel frames, built-up roofs, and } \\
\text { some concrete structures, depending on the } \\
\text { thickness. }\end{array}$ \\
\hline
\end{tabular}


Table 23.

Controlled Collapse (Continued)

\begin{tabular}{|l|l|}
\hline Theory of Operation & $\begin{array}{l}\text { Buiding structure is ailowed to faii in a } \\
\text { confined area using mechanical means such } \\
\text { as a bulldozer, back hoe, or other heavy } \\
\text { machinery. }\end{array}$ \\
\hline Previous Product Users & U.S. DOE sites, e.g., Fernald. \\
\hline
\end{tabular}

Table 24.

High Pressure Water Blasting

\begin{tabular}{|l|l|}
\hline Technology Name & High Pressure Water Blasting \\
\hline $\begin{array}{l}\text { Technology's Industrial Status } \\
\text { current or innovative) }\end{array}$ & Current \\
\hline Vendor Name & U.S. Dismantlement \\
\hline Fax Number & $(312) 685-8378$ \\
\hline Benefits & $\begin{array}{l}\text { High pressurization of working fluid (up to } \\
4000 \text { bars) results in efficient demolition. }\end{array}$ \\
\hline Limitations & Water and power supply. \\
\hline Method & $\begin{array}{l}\text { High pressure water jet with flexible hose } \\
\text { attachments. }\end{array}$ \\
\hline Applicable Building Type & $\begin{array}{l}\text { Concrete matrix material; reinforced } \\
\text { concrete. }\end{array}$ \\
\hline Theory of Operation & $\begin{array}{l}\text { Works by the generation of a high pressure } \\
\text { water jet, which is directed through a fine } \\
\text { nozzle to impact a work piece. }\end{array}$ \\
\hline Previous Product Users & \begin{tabular}{l} 
U.S. DoE sites \\
\hline
\end{tabular}
\end{tabular}




\section{Table 25.}

Hydraulic Hammers

\begin{tabular}{|l|l|}
\hline Techrology Name & Hydraulic Hammers \\
\hline $\begin{array}{l}\text { Technology's Industrial Status } \\
\text { (current or innovative) }\end{array}$ & Current \\
\hline Vendor Name & U.S. Dismantlement \\
\hline Fax Number & $(312) 685-8378$ \\
\hline Benefits & High impact energy pulses \\
\hline Limitations & Space constraints \\
\hline Method & High impact hammer \\
\hline Applicable Building Type & Concrete structures \\
\hline Theory of Operation & $\begin{array}{l}\text { Mechanically powered device is used to dismantle } \\
\text { concrete structures through the use of high impact } \\
\text { forces. }\end{array}$ \\
\hline Previous Product Users & JCB Hydropower (UK); U.S. DOE sites \\
\hline
\end{tabular}

Table 26.

\section{Drilling and Splitting}

\begin{tabular}{|l|l|}
\hline Technology Name & Drilling and Splitting \\
\hline $\begin{array}{l}\text { Technology's Industrial Status } \\
\text { (current or innovative) }\end{array}$ & Current \\
\hline Vendor Name & U.S. Dismantlement \\
\hline Fax Number & $(312) 685-8378$ \\
\hline Benefits & Low dust aerosol generation \\
\hline Limitations & $\begin{array}{l}\text { Best on concrete structures; effectiveness decreases } \\
\text { when used on reinforced concrete material. }\end{array}$ \\
\hline Method & $\begin{array}{l}\text { Expansion of concrete material using hydraulic } \\
\text { pressure/force. }\end{array}$ \\
\hline Applicable Building Type & Concrete structures \\
\hline Theory of Operation & $\begin{array}{l}\text { Concrete is expanded via a hydraulic cylinder } \\
\text { attached to an expanding mandrel. }\end{array}$ \\
\hline Previous Product Users & $\begin{array}{l}\text { Enerpac, Ltd. (UK); wrecking companies; U.S. } \\
\text { DOE sites. }\end{array}$ \\
\hline
\end{tabular}


Table 27.

Balling Air Jackhammer

\begin{tabular}{|l|l|}
\hline Technoiogy Name & Bäling Air Jackhianmer \\
\hline $\begin{array}{l}\text { Technology's Industrial Status (current or } \\
\text { innovative) }\end{array}$ & Current \\
\hline Vendor Name & U.S. Dismantlement \\
\hline Fax Number & $(312) 685-8378$ \\
\hline Benefits & $\begin{array}{l}\text { Ability to cut through thick concrete } \\
\text { material. }\end{array}$ \\
\hline Limitations & $\begin{array}{l}\text { Poor dust control during operation due to } \\
\text { fragmented projectile motion of material } \\
\text { debris. High vibrational forces on workers } \\
\text { due to operation. }\end{array}$ \\
\hline Method & $\begin{array}{l}\text { Use of a mechanical hammer to chip, crush, } \\
\text { or separate material. }\end{array}$ \\
\hline Applicable Building Type & Concrete \\
\hline Theory of Operation & $\begin{array}{l}\text { A high impact hydraulic force is produced } \\
\text { by a manually operated mechanical } \\
\text { hammer. }\end{array}$ \\
\hline Previous Product Users & Wrecking companies; U.S. DOE sites \\
\hline
\end{tabular}


Table 28.

Controlled Explosion

\begin{tabular}{|l|l|}
\hline Technology Name & Controlled Explosion \\
\hline $\begin{array}{l}\text { Technology's Industrial Status } \\
\text { (current or innovative) }\end{array}$ & Current \\
\hline Vendor Name & British Aerospace Defense \\
\hline Fax Number & $44-1257-265511$ \\
\hline Benefits & Very fast process. \\
\hline Limitations & $\begin{array}{l}\text { The pressure produced in a closed building } \\
\text { will have implications for any ventilation } \\
\text { systems present. }\end{array}$ \\
\hline Method & Controlled explosives \\
\hline Applicable Building Type & All \\
\hline Theory of Operation & $\begin{array}{l}\text { This process uses explosive charges at } \\
\text { strategic points within or around a structure } \\
\text { in order to effect a cut. }\end{array}$ \\
\hline Previous Product Users & $\begin{array}{l}\text { Babcock and Wilcox; U.S. DOE sites, e.g., } \\
\text { Fernald }\end{array}$ \\
\hline
\end{tabular}


Mathematical Correlations for the Prediction of the Number of Airborne Dust Particles under Different D\&D Conditions

Non-Plastered 4" Block, No Suppression, No Wind

$z=a+b / x+c / y+d / x^{2}+e / y^{2}+f /(x y)+g / x^{3}+h / y^{3}+i /\left(x y^{2}\right)+j /\left(x^{2} y\right)$

$r^{2}=0.8403$

$\begin{array}{lll}a=-3.6308 \times 10^{8} & b=-9.3185 \times 10^{11} & c=48443.227 \\ e=-0.0015 & f=-19312575 & g=-4.5170 \times 10^{16} \\ i=0.2551 & j=1.9371 \times 10^{9} & \\ \text { Non-Plastered 4" Block, Polymeric Barrier Suppression, No Wind }\end{array}$

$\ln z=a+b / x^{1.5}+c \ln x / x^{2}+d(\ln y)^{2}+e(\ln y)^{2}+f / y^{0.5}+g \ln y / y+h / y$

$r^{2}=0.9562$

$\mathrm{a}=-1855.1533$

$b=-2427514$

$\mathrm{c}=5387022.7$

$d=-21.644$

$e=-403.9167$

$\mathrm{f}=0.8885$

$\mathrm{g}=-6.9704 \times 10^{-5}$

$\mathrm{h}=-0.00128$

Non-Plastered 4" Block, Coherex Additive Suppression, No Wind

$$
\begin{array}{llll}
\left.\mathrm{z}=\mathrm{a}+\mathrm{b} \ln \mathrm{x}+\mathrm{c} / \mathrm{y}+\mathrm{d} /(\ln \mathrm{x})^{2}+\mathrm{e} / \mathrm{y}^{2}+\mathrm{f}(\ln \mathrm{x}) / \mathrm{y}+\mathrm{g}(\ln \mathrm{x})^{3}+\mathrm{h} / \mathrm{y}^{3}+\mathrm{i}(\ln \mathrm{x}) / \mathrm{y}^{2}+\mathrm{j}(\ln \mathrm{n})^{2} / \mathrm{y}\right) \\
\mathrm{r}^{2}=0.9637 & & \\
\mathrm{a}=1.7929 \times 10^{10} & \mathrm{~b}=-3.5567 \times 10^{9} & \mathrm{c}=-14163.215 & \mathrm{~d}=-5.3424 \times 10^{8} \\
\mathrm{e}=0.0023 & \mathrm{f}=2770.8542 & \mathrm{~g}=1.0667 \times 10^{8} & \mathrm{~h}=1.2449 \times 10^{-10} \\
\mathrm{i}=-0.000524 & \mathrm{j}=1.2159 & &
\end{array}
$$

Non-Plastered 4" Block, Water Suppression, No Wind

$$
\begin{array}{llll}
z=a+b x+c / y+d x^{2}+e / y^{2}+f x / y+g x^{3}+h / y^{3}+i x / y^{2}+j x^{2} / y & \\
r^{2}=0.9787 & & \\
a=3.8789 \times 10^{8} & b=-2803265.8 & c=13976.006 & d=-747.8264 \\
e=-0.00016 & f=-137.3086 & g=22.0887 & h=5.3366 \times 10^{-11}
\end{array}
$$


$\mathrm{i}=-1.7532 \times 10^{-7} \quad \mathrm{j}=0.3433$

Plastered 4" Biock, No Suppression, No Wind

$\ln z=a+b x^{2} \ln x+c x^{2.5}+d y^{0.5} \ln y+e(\ln y)^{2}+f y^{0.5}$

$r^{2}=0.9337$

$a=-10.3243$

$b=-0.00089$

$c=0.00029$

$d=-4446.7007$

$\mathrm{e}=0.1703$

$f=-43467.052$

Plastered 4" Block, Polymeric Barrier Suppression, No Wind

$z=a+b / x+c / y+d / x^{2}+e / y^{2}+f /(x y)+g / x^{3}+h / y^{3}+i /\left(x y^{2}\right)+j /\left(x^{2} y\right)$

$r^{2}=0.9193$

$a=-29473757$

$b=-3.7795 \times 10^{10}$

$c=3432.2656$

$\mathrm{d}=1.5148 \times 10^{13}$

$\mathrm{e}=-0.00026$

$\mathrm{f}=-1252272.4$

$\mathrm{g}=-1.3474 \times 10^{15}$

$h=2.7844 \times 10^{-11}$

$\mathrm{i}=0.0329$

$\mathrm{j}=1.1794 \times 10^{8}$

Plastered 4" Block, Coherex Additive Suppression, No Wind

$\ln z=a+b x^{1.5}+c x^{2.5}+d / y^{0.5}+e \ln y / y+f / y+g / y^{1.5}$

$r^{2}=0.9191$

$\mathrm{a}=11.8679$

$b=-0.0236$

$\mathrm{c}=7.3742 \times 10^{-5}$

$\mathrm{d}=0.2147$

$e=-0.00012$

$f=-0.00172$

$\mathrm{g}=-7.9962 \times 10^{-8}$

Plastered 4" Block, Water Suppression, No Wind

$\ln z=a+b \ln x / x+c / x+d / y^{0.5}+e \ln y / y+f / y+g / y^{1.5}$

$r^{2}=0.9840$

$\mathrm{a}=-29.3384$

$\mathrm{b}=5533.7711$

$c=-25393.259$

$d=0.1740$

$e=-9.0474 \times 10^{-5}$

$f=-0.00134$

$\mathrm{g}=-5.9489 \times 10^{-8}$

Non-Plastered 8" Block, No Suppression, No Wind

$z=a+b x+c / y+d x^{2}+e / y^{2}+f x / y+g x^{3}+b / y^{3}+i x / y^{2}+j x^{2} / y$

$r^{2}=0.7655$

$a=2.3528 \times 10^{9}$

$b=-31855964$

$c=-9356.8848$

$d=143665.55$ 


$$
\begin{array}{llll}
e=0.00038 & f=81.7443 & g=219.6845 & h=4.5754 \times 10^{-11} \\
i=-2.8414 \times 10^{-6} & j=-0.1632 &
\end{array}
$$

Non-Plastered 8" Block, Polymeric Barrier Suppression, No Wind

$$
\begin{array}{llll}
z=a+b / x+c / y+d / x^{2}+e / y^{2}+f /(x y)+g / x^{3}+h / y^{3}+i /\left(x y^{2}\right)+j /\left(x^{2} y\right) & \\
r^{2}=0.8144 & & & \\
a=-3.2504 \times 10^{8} & b=7.6077 \times 10^{10} & c=-11823.069 . & d=2.2195 \times 10^{12} \\
e=0.00011 & f=4948826.5 & g=-9.7059 \times 10^{14} & h=-1.6275 \times 10^{-12} \\
i=-0.0224 & j=-5.0782 \times 10^{8} & &
\end{array}
$$

Non-Plastered 8" Block, Coherex Additive Suppression, No Wind

$$
\begin{array}{llll}
z=a+b x+c l n y+d x^{2}+e(\ln y)^{2}+f x \ln y+g x^{3}+h(\ln y)^{3}+i x(\ln y)^{2}+j x^{2} \ln y \\
r^{2}=0.6633 & & & \\
a=6.1239 \times 10^{8} & b=17066497 & c=4.0551 \times 10^{8} & d=-185835.41 \\
e=7467451.4 & f=-3072098.7 & g=285.8681 & h=-635966.21 \\
i=-151731.41 & j=-1689.9991 & &
\end{array}
$$

Non-Plastered 8" Block, Water Suppression, No Wind

$$
\begin{array}{llll}
z=a+b / x+c / y+d / x^{2}+e / y^{2}+f /(x y)+g / x^{3}+h / y^{3}+i /\left(x y^{2}\right)+j /\left(x^{2} y\right) \\
r^{2}=0.6991 & & & \\
a=1.7214 \times 10^{8} & b=4.7101 \times 10^{10} & c=-11469.756 & d=-3.1344 \times 10^{13} \\
e=-0.00108 & f=4994917.3 & g=2.7300 \times 10^{15} & h=1.7761 \times 10^{-10} \\
i=0.0992 & j=-5.1225 \times 10^{8} & &
\end{array}
$$

Plastered 8" Block, No Suppression, No Wind

$$
\begin{array}{llll}
z=a+b x+c l n y+d x^{2}+e(\ln y)^{2}+f x \ln y+g x^{3}+h(\ln y)^{3}+i x(\ln y)^{2}+j x^{2} \ln y \\
r^{2}=0.6335 \\
a=-2.2779 \times 10^{10} & b=3.7879 \times 10^{8} & c=9.0839 \times 10^{8} & d=-2851711 \\
e=-2.4215 \times 10^{8} & f=-36265066 & g=6490.193 & h=-6546912.1
\end{array}
$$$$
\mathrm{i}=144429.78 \quad \mathrm{j}=98931.841
$$ 
Plastered 8" Block, Polymeric Barrier Suppression, No Wind

$z=a+b x \ln x+c x^{1.5}+d(\ln y)^{2}+e \ln y+f / y^{0.5}+g \ln y / y+h / y+i / y^{1.5}$

$r^{2}=0.6461$

$a=-2.8531 \times 10^{12} \quad b=-1430945.2 \quad c=566728.93 \quad d=-4.3482 \times 10^{10}$

$e=-6.7105 \times 10^{11} \quad f=4.0655 \times 10^{9} \quad g=-888551.62 \quad h=-14049363$

$\mathrm{i}=-411.0727$

Plastered 8" Block, Coherex Additive Suppression, No Wind

$z=a+b x+c \ln y+d x^{2}+e(\ln y)^{2}+f x \ln y+g x^{3}+h(\ln y)^{3}+i x(\ln y)^{2}+j x^{2} \ln y$

$r^{2}=0.5515$

$a=-1.4336 \times 10^{10} \quad b=-98228088 \quad c=-5.7136 \times 10^{9} \quad d=770828$

$e=-3.0764 \times 10^{8} \quad f=17474812 \quad g=-3654.2006 \quad h=-16247874$

$\mathrm{i}=-1540797.7 \quad \mathrm{j}=-138284.48$

Plastered 8" Block, Water Suppression, No Wind

$z=a+b x+c \ln y+d x^{2}+e(\ln y)^{2}+f x \ln y+g x^{3}+h(\ln y)^{3}+i x(\ln y)^{2}+j x^{2} \ln y$

$r^{2}=0.5315$

$a=-5.3186 \times 10^{10} \quad b=5.1825 \times 10^{8} \quad c=-3.8956 \times 10^{9} \quad d=-4627198.5$

$e=-9.4754 \times 10^{8} \quad f=-75110033 \quad g=13742.594 \quad h=-13982166$

$\mathrm{i}=2263966.6 \quad \mathrm{j}=323116.46$

Solid Block, No Suppression, No Wind

$z=a+b x+c / y+d x^{2}+e / y^{2}+f x / y+g x^{3}+h / y^{3}+i x / y^{2}+j x^{2} / y$

$r^{2}=0.6844$

$a=1.0722 \times 10^{10} \quad b=-1.3701 \times 10^{8} \quad c=12800.995 \quad d=570002.819$

$\mathrm{e}=0.00064 \mathrm{f}=135.5751 \quad \mathrm{~g}=-771.4673 \quad \mathrm{~h}=5.7289 \times 10^{-11}$

$\mathrm{i}=-4.5048 \times 10^{-6} \quad \mathrm{j}=0.3687$

Solid Block, Polymeric Barrier Suppression, No Wind

$z=a+b x+c / y+d x^{2}+e / y^{2}+f x / y+g x^{3}+h / y^{3}+i x / y^{2}+j x^{2} / y$

$r^{2}=0.9776$ 

$a=19853244$
$b=-23439.115$
$c=-128.2098$
$d=-3436.1011$
$e=-0.00024$
$f=8.2647$
$\mathrm{g}=12.8053$
$\mathrm{h}=4.4380 \times 10^{-11}$
$i=3.8144 \times 10^{7}, \quad j=-0.03161$

Solid Block, Coherex Additive Suppression, No Wind

$z=a+b x+c x \ln y+d(\ln y)^{2}+e / y^{0.5}+$ flny $/ y+g / y+h / y^{2}$

$r^{2}=0.9805$

$\begin{array}{llll}a=-1.2055 \times 10^{10} & b=4.3006 \times 10^{8} & c=-68514714 & d=-20340446 \\ e=5819515.7 & f=-693.9030 & g=-12800.047 & h=0.00011\end{array}$

\section{Solid Block, Water Suppression, No Wind}

$z=a+b x+c / y+d x^{2}+e / y^{2}+f x / y+g x^{3}+h / y^{3}+i x / y^{2}+j x^{2} / y$

$r^{2}=0.7508$

$\mathrm{a}=4.9246 \times 10^{9}$

$b=-17122980$

$\mathrm{c}=-5730.0812$

$\mathrm{d}=-200881.02$

$\mathrm{e}=-0.00011$

$\mathrm{f}=51.5923$

$\mathrm{g}=805.9257$

$\mathrm{h}=1.4336 \times 10^{-10}$

$\mathrm{i}=-2.0252 \times 10^{-6} \quad \mathrm{j}=-0.0985$

Non-Plastered 4" Block, No Suppression, Wind

$z=a+b x+c / y+d x^{2}+e / y^{2}+f x / y+g x^{3}+h / y^{3}+i x / y^{2}+j x^{2} / y$

$r^{2}=0.7736$

$\mathrm{a}=-4.9870 \times 10^{9}$

$\mathrm{b}=41702812$

$c=28656.063$

$\mathrm{d}=-41522.477$

$\mathrm{e}=0.0011$

$\mathrm{f}=-293.1951$

$g=-213.5847$

$\mathrm{h}=1.0140 \times 10^{-10}$

$i=-7.2332 \times 10^{-6} \quad j=0.7651$

Non-Plastered 4" Block, Polymeric Barrier Suppression, Wind

$z=\left(a+b \ln x+c \ln y+d(\ln y)^{2}+e(\ln y)^{3}\right) /\left(1+f \ln x+g(\ln x)^{2}+h \ln y+i(\ln y)^{2}\right)$

$r^{2}=0.9163$

$\mathrm{a}=4923527$

$b=-2342.6911$

$c=1415390.7$

$\mathrm{d}=135955.92$

$\mathrm{e}=4350.0015$

$f=-0.3717$

$\mathrm{g}=0.0350$

$\mathrm{h}=0.0018$

$\mathrm{i}=6.3387 \times 10^{-5}$ 
Non-Plastered 4" Block, Coherex Additive Suppression, Wind

$$
\begin{array}{llll}
z=a+b / x+c / y+d / x^{2}+e / y^{2}+f /(x y)+g / x^{3}+h / y^{3}+i /\left(x y^{2}\right)+j /\left(x^{2} y\right) \\
r^{2}=0.9357 & & & \\
a=2.1623 \times 10^{10} & b=9.6426 \times 10^{12} & c=-9693.3303 & d=-1.2384 \times 10^{15} \\
e=-0.0014 & f=4070630.2 & g=3.4957 \times 10^{16} & h=1.6680 \times 10^{-10} \\
i=0.1523 & j=-3.8218 \times 10^{8} & &
\end{array}
$$

\section{Non-Plastered 4" Block, Water Suppression, Wind}

$$
\begin{array}{llll}
z=a+b x+c / y+d x^{2}+e / y^{2}+f x / y+g x^{3}+h / y^{3}+i x / y^{2}+j x^{2} / y & \\
r^{2}=0.7651 & & \\
a=-1.5454 \times 10^{9} & b=2088285.2 & c=12875.142 & d=81677.26 \\
e=-0.00035 & f=-110.8263 & g=-273.1613 & h=4.7812 \times 10^{-11} \\
i=4.3638 \times 10^{-7} & j=0.2555 & &
\end{array}
$$

\section{Plastered 4" Block, No Suppression, Wind}

$z=a+b / x+c / y+d / x^{2}+e / y^{2}+f /(x y)+g / x^{3}+h / y^{3}+i /\left(x y^{2}\right)+j /\left(x^{2} y\right)$

$r^{2}=0.7864$

$$
\begin{array}{llll}
a=-5.6215 \times 10^{9} & b=2.3894 \times 10^{12} & c=-41229.657 & d=-2.9077 \times 10^{14} \\
e=0.00103 & f=16637924 & g=6.9931 \times 10^{15} & h=3.8222 \times 10^{-10} \\
i=-0.4891 & j=-1.5932 \times 10^{9} & &
\end{array}
$$

Plastered 4" Block, Polymeric Barrier Suppression, Wind

$$
\begin{array}{llll}
z=a+b / x+c / y+d / x^{2}+e / y^{2}+f /(x y)+g / x^{3}+h / y^{3}+i /\left(x y^{2}\right)+j /\left(x^{2} y\right) \\
r^{2}=0.9440 \\
a=-9.6994 \times 10^{10} & b=6.3459 \times 10^{13} & c=-91804.287 & d=-1.3753 \times 10^{16} \\
e=-0.00065 & f=37706647 & g=9.8615 \times 10^{17} & h=2.3405 \times 10^{-10} \\
i=-0.0496 & j=-3.7983 \times 10^{9} & &
\end{array}
$$

Plastered 4" Block, Coherex Additive Suppression, Wind

$$
\begin{aligned}
& z=a+b / x+c / y+d / y^{2}+e / y^{3}+f / y^{4} \\
& r^{2}=0.9422
\end{aligned}
$$




$$
\begin{array}{llll}
a=-3.2540 \times 10^{9} & b=6.8719 \times 10^{11} & c=-404.0846 & d=0.00604 \\
e=-5.8069 \times 10^{-9} & f=1.3920 \times 10^{-15} &
\end{array}
$$

\section{Plastered 4" Block, Water Suppression, Wind}

$$
\begin{array}{llll}
z=a+b / x+c / y+d / x^{2}+e / y^{2}+f /(x y)+g / x^{3}+h / y^{3}+i /\left(x y^{2}\right)+j /\left(x^{2} y\right) \\
r^{2}=0.8189 & & & \\
a=5.4236 \times 10^{9} & b=-2.8033 \times 10^{11} & c=-120912.89 & d=-5.7736 \times 10^{14} \\
e=-0.00132 & f=49593769 & g=8.1574 \times 10^{16} & h=3.8108 \times 10^{-10} \\
i=-0.0143 & j=-4.9861 \times 10^{9} & &
\end{array}
$$

Non-Plastered 8" Block, No Suppression, Wind

$$
\begin{array}{llll}
z=a+b x+c / y+d x^{2}+e / y^{2}+f x / y+g x^{3}+h / y^{3}+i x / y^{2}+j x^{2} / y & \\
r^{2}=0.7328 & & & \\
a=3.1500 \times 10^{9} & b=-55785453 & c=58739.373 & d=262410.33 \\
e=-0.00236 & f=-526.9508 & g=-322.7407 & h=1.6584 \times 10^{-10} \\
i=7.7131 \times 10^{-6} & j=1.2049 & &
\end{array}
$$

Non-Plastered 8" Block, Polymeric Barrier Suppression, Wind

$$
\begin{array}{llll}
z=a+b x+c / y+d x^{2}+e / y^{2}+f x / y+g x^{3}+h / y^{3}+i x / y^{2}+j x^{2} / y & \\
r^{2}=0.8101 & & & \\
a=2.6344 \times 10^{9} & b=-14328628 & c=51705.261 d=-104411.42 \\
e=-0.0022 & f=-451.7554 & g=538.3981 & h=1.0660 \times 10^{-9} \\
i=-6.6485 \times 10^{-6} & j=1.0720 & &
\end{array}
$$

Non-Plastered 8" Block, Coherex Additive Suppression, Wind

$$
\begin{array}{llll}
z=a+b x+c \ln y+d x^{2}+e(\ln y)^{2}+f x \ln y+g x^{3}+h(\ln y)^{3}+i x(\ln y)^{2}+j x^{2} \ln y \\
r^{2}=0.7192 & & \\
a=-1.9267 \times 10^{11} & b=3.3276 \times 10^{9} & c=8.1113 \times 10^{9} & d=-23470143 \\
e=-1.2009 \times 10^{9} & f=-2.3032 \times 10^{8} & g=43780.324 & h=-61808446 \\
i=-5355147.3 & j=248125.74 & &
\end{array}
$$


Non-Plastered 8" Block, Water Suppression, Wind

$$
\begin{array}{llll}
z=a+b \ln x+c / y+d(\ln x)^{2}+e / y^{2}+f(\ln x) / y+g(\ln x)^{3}+h / y^{3}+i(\ln x) / y^{2}+j(\ln x)^{2} / y \\
r^{2}=0.7226 & & & \\
a=-5.0116 \times 10^{10} & b=3.8765 \times 10^{10} & c=-205414 & d=-9.1240 \times 10^{9} \\
e=0.0376 & f=70122.394 & g=6.7745 \times 10^{8} & h=9.5600 \times 10^{-11} \\
i=-0.0072 & j=5878.7184 & &
\end{array}
$$

\section{Plastered 8" Block, No Suppression, Wind}

$$
\begin{array}{llll}
z=a+b x+c / y+d x^{2}+e / y^{2}+f x / y+g x^{3}+h / y^{3}+i x / y^{2}+j x^{2} / y & \\
r^{2}=0.9203 & & \\
a=1.7301 \times 10^{10} & b=-1.1310 \times 10^{8} & c=-40401.707 & d=-172984.75 \\
e=-0.0107 & f=473.3731 & g=1516.0984 & h=3.6567 \times 10^{-10} \\
i=4.9877 \times 10^{-5} & j=-1.3219 & &
\end{array}
$$

Plastered 8" Block, Polymeric Barrier Suppression, Wind

$$
\begin{array}{llll}
z=a+b / x+c / y+d / x^{2}+e / y^{2}+f /(x y)+g / x^{3}+h / y^{3}+i /\left(x y^{2}\right)+j /\left(x^{2} y\right) \\
r^{2}=0.8596 & & & \\
a=1.8086 \times 10^{9} & b=-2.2465 \times 10^{11} & c=-3050.3282 & d=-1.1513 \times 10^{14} \\
e=0.0017 & f=717631.14 & g=1.7378 \times 10^{16} & h=-3.3277 \times 10^{-10} \\
i=-0.1412 & j=-13268715 & &
\end{array}
$$

Plastered 8" Block, Coherex Additive Suppression, Wind

$z=a+b / x+c \ln y+d / x^{2}+e(\ln y)^{2}+f(\ln y) / x+g / x^{3}+h(\ln y)^{3}+i(\ln y)^{2} / x+j(\ln y) / x^{2}$

$r^{2}=0.6735$

$$
\begin{array}{llll}
a=1.6278 \times 10^{9} & b=-4.4509 \times 10^{13} & c=-1.6213 \times 10^{10} & d=-9.4983 \times 10^{15} \\
e=-4.2430 \times 10^{9} & f=-1.4984 \times 10^{13} & g=1.6208 \times 10^{18} & h=-1.2932 \times 10^{8} \\
i=-1.2466 \times 10^{11} & j=1.2005 \times 10^{15} & &
\end{array}
$$

\section{Plastered 8" Block, Water Suppression, Wind}

$\mathrm{z}=\mathrm{a}+\mathrm{b} / \mathrm{x}+\mathrm{c} \ln \mathrm{y}+\mathrm{d} / \mathrm{x}^{2}+\mathrm{e}(\ln \mathrm{y})^{2}+\mathrm{f}(\ln \mathrm{y}) / \mathrm{x}+\mathrm{g} / \mathrm{x}^{3}+\mathrm{h}(\ln \mathrm{y})^{3}+\mathrm{i}(\ln \mathrm{y})^{2} / \mathrm{x}+\mathrm{j}(\ln \mathrm{y}) / \mathrm{x}^{2}$

$r^{2}=0.7261$ 


$$
\begin{array}{llll}
a=-1.3772 \times 10^{12} & b=5.7325 \times 10^{14} & c=-1.0698 \times 10^{11} & d=-9.8882 \times 10^{16} \\
e=-5.7600 \times 10^{9} & f=1.4298 \times 10^{13} & g=5.9740 \times 10^{18} & h=-1.2351 \times 10^{8} \\
i=2.3032 \times 10^{i 1}, & j=-8.6944 \times 10^{i 4} & &
\end{array}
$$

Solid Block, No Suppression, Wind

$z=a+b x+c / y+d x^{2}+e / y^{2}+f x / y+g x^{3}+h / y^{3}+i x / y^{2}+j x^{2} / y$

$r^{2}=0.9024$

$\mathrm{a}=1.5385 \times 10^{9} \quad \mathrm{~b}=-62592501 \quad \mathrm{c}=44023.75 \quad \mathrm{~d}=506445.41$

$\mathrm{e}=-0.0028 \quad \mathrm{f}=-424.2361 \quad \mathrm{~g}=-1163.669 \quad \mathrm{~h}=1.5364 \times 10^{-10}$

$i=1.1209 \times 10^{-5} \quad j=1.0407$

Solid Block, Polymeric Barrier Suppression, Wind

$z=a+b / x+c / y+d / x^{2}+e / y^{2}+f /(x y)+g / x^{3}+h / y^{3}+i /\left(x y^{2}\right)+j /\left(x^{2} y\right)$

$r^{2}=0.9913$

$\mathrm{a}=55320511 \quad \mathrm{~b}=-3.4872 \times 10^{10} \quad \mathrm{c}=2091.8804 \quad \mathrm{~d}=6.8316 \times 10^{12}$

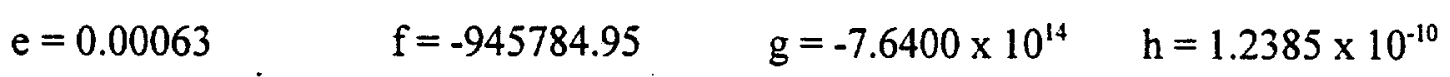

$\mathrm{i}=-0.2084 \quad \mathrm{j}=1.2812 \times 10^{8}$

Solid Block, Coherex Additive Suppression, Wind

$z=a+b / x+c / y+d / x^{2}+e / y^{2}+f /(x y)+g / x^{3}+h / y^{3}+i /\left(x y^{2}\right)+j /\left(x^{2} y\right)$

$r^{2}=0.9905$

$a=2.1696 \times 10^{8} \quad b=7.4009 \times 10^{9} \quad c=-12477.19 \quad d=-3.2154 \times 10^{13}$

$\mathrm{e}=0.0003 \quad \mathrm{f}=5125406.8 \quad \mathrm{~g}=3.9422 \times 10^{15} \quad \mathrm{~h}=1.3063 \times 10^{-10}$

$i=-0.1557 \quad j=-4.9599 \times 10^{8}$

Solid Block. Water Suppression, Wind

$$
\begin{array}{llll}
z=a+b / x+c / y+d / x^{2}+e / y^{2}+f /(x y)+g / x^{3}+h / y^{3}+i /\left(x y^{2}\right)+j /\left(x^{2} y\right) \\
r^{2}=.8528 & & \\
a=-4.0640 \times 10^{9} & b=4.1481 \times 10^{11} & c=25552.03 & d=3.1870 \times 10^{14} \\
e=-0.0013 & f=-9969082.9 & g=-4.7796 \times 10^{16} & h=1.6860 \times 10^{-10} \\
i=0.1490 & j=9.9210 \times 10^{8} & &
\end{array}
$$

